OPEN ACCESS

Edited by:

Xun Zhang,

Academy of Mathematics and Systems Science (CAS), China

Reviewed by:

Muhammad Mohsin,

Jiangsu University, China Xuerong $\mathrm{Li}$,

Academy of Mathematics and Systems Science (CAS), China

${ }^{*}$ Correspondence: Zhenzhen Wang wangzhzh@gdufs.edu.cn

Specialty section: This article was submitted to Sustainable Energy Systems and Policies,

a section of the journal Frontiers in Energy Research

Received: 11 July 2021 Accepted: 12 November 2021 Published: 03 January 2022

Citation:

Jia S, Dong H and Wang Z (2022) Identifying the Asymmetric Channel of Crude Oil Risk Pass-Through to Macro

Economy: Based on Crude

Oil Attributes.

Front. Energy Res. 9:739653.

doi: 10.3389/fenrg.2021.739653

\section{Identifying the Asymmetric Channel of Crude Oil Risk Pass-Through to Macro Economy: Based on Crude Oil Attributes}

\author{
Shuaishuai Jia ${ }^{1}$, Hao Dong ${ }^{2}$ and Zhenzhen Wang ${ }^{3 *}$ \\ ${ }^{1}$ Guangzhou Institute of International Finance, Guangzhou University, Guangzhou, China, ${ }^{2}$ Lingnan (University) College, Sun Yat- \\ Sen University, Guangzhou, China, ${ }^{3}$ School of Mathematics and Statistics, Guangdong University of Foreign Studies, \\ Guangzhou, China
}

The impact channel of crude oil market risk on the macroeconomy is highly related to oil attributes. This paper uses a stepwise test method with dummy variables to identify the channel effect of commodity market risk as well as financial market risk and explore the characteristics of the channel effect in different periods dominated by different oil attributes. Furthermore, this paper investigates the asymmetric characteristics of the channel effect under the condition of crude oil returns heterogeneity. The empirical results show that: First, commodity market risk, as well as financial market risk plays a channel role in the impact of crude oil market risk on the macroeconomic operation. Second, there is a significant difference in the ability of the commodity market and financial market to cope with shocks of crude oil market risk in periods dominated by different attributes. During the period dominated by the commodity attribute of oil, both commodity market and financial market play the role of "risk buffer"; during the period dominated by dual attributes of oil, the commodity market risk plays the role of "risk buffer", while the financial market risk plays the role of "magnifier" of the crude oil market risk. Third, the channel effect pattern and degree of commodity market risk and financial market risk are significantly asymmetric.

Keywords: channel identification, upward and downward return risk, macro economy, Commodity market, financial market

\section{INTRODUCTION}

The impact of crude oil market risk on the smooth operation of the macroeconomy is related to the dual attributes of the oil. As a key input factor, the price fluctuation of crude oil will directly or indirectly affect macroeconomic factors such as inflation, interest rate and price level (Bloch et al., 2015; Ratti and Vespignani, 2016; Sodeyfifi and Katircioglu, 2016; Kang et al., 2017; Shi and Sun, 2017; Ji et al., 2019a; Saeed and Ridoy, 2020). The dependence of economic development on crude oil is the main factor that determines the direct shock of the crude oil market. Since 1993, China has become a net importer of crude oil, and the import volume shows an upward trend. In 2014, China became the world's largest importer of crude oil. China's consumption of crude oil is also on the rise, making it the second-largest consumer of crude after the United States. In addition, the commodity and financial attributes of oil reflect the indirect impact of the crude oil market on the smooth operation of the macroeconomy. Crude oil, on the one hand as the main commodity, its price 
fluctuation will cause the price of other commodities to change in the same direction; on the other hand, as the necessity of production and life, the change of its price as well as the change of other commodities prices will inevitably lead to the change of many macroeconomic indicators, such as the price level. In addition, due to the influence of demand, the international crude oil market price has a great uncertainty, which in turn changes the macroeconomic operation (Guo et al., 2016; Choi et al., 2018; Gong and Lin, 2018; Humbatova et al., 2019). Given this, violent oil price fluctuations must have an impact on the smooth operation of the economy, and the impact of the crude oil market on the economy is heterogeneous under different oil attributes.

The focus of investigating the ability of the commodity market and financial market to cope with the oil market risk impact is mainly on the channel effect. In terms of commodity markets, on the one hand, China, as the largest importer, could be changed by the fluctuation of crude oil price, thus affecting the supply of crude oil. Moreover, changes in crude oil market price would lead to changes in commodity market price, which indirectly affect economic development (Ji et al., 2018). On the other hand, China focuses on strengthening the energy reserves and infrastructures construction to buffer shocks of the external environment. The decline of crude oil market price reduces the constraints of the cost factor on China and provides conditions for expanding energy reserves and increasing energy infrastructure construction. From the perspective of the financial market, the negative correlation between crude oil price and the financial market creates more profit space for investors, especially fund investors (Wen et al., 2019a; Zheng and Du 2019). Investors take crude oil as a hedge asset, grasp the downward trend of crude oil prices, and obtain excess profits in a short time. This kind of capital flow challenges the effectiveness of the financial market and then affects economic development (Ji et al., 2019a; Meng et al., 2020).

The main purpose of this paper is to identify the channels through which crude oil market risk affects macroeconomic operation and to analyze the asymmetric characteristics of channel effect under the condition of oil returns heterogeneity. The formation of dual attributes of oil has enhanced the channel effect of the commodity market as well as a financial market in the impact of the crude oil market on economic development. In addition, the rise and fall of returns in the crude oil market will affect the speed of obtaining market information and investors' expectations, thus the correlation between risks in the crude oil market and commodity market is different from that between risks in the crude oil market and financial market (Cheng et al., 2016; Ji et al., 2019a; Wu et al., 2021). The financial attribute of crude oil has attracted more and more investors to consider oil as a financial commodity while providing opportunities for speculators. Due to the heterogeneity of information access between investors and speculators, investors and speculators have different responses to market price fluctuations under different trends (Ahmed et al., 2017; Ji et al., 2019b). This paper investigates the asymmetric impact of the international crude oil market risks on the stable economic operation from the perspective of the rising and falling returns of the crude oil market, which is conducive to improving the cross-market information sharing mechanism and preventing the shock from the price fluctuation in the international crude oil market to the stable economic operation.

The existing literature mainly identifies the impact channels of the crude oil market and price level. Alvarez et al. (2011) analyzed the indirect effect of the crude oil market on price levels in Spain and Europe. Razmi et al. (2016) investigated the mediating mechanism of currency in the impact of crude oil price on the price level. The results show that before the financial crisis, the mediating effect of currency is not obvious, but after the financial crisis, the price of crude oil will not only directly affect the price level, but also have an indirect effect on the price level through currency. In addition, the interaction mechanism between crude oil price and price level can also be realized through other channels, such as the channel of interest rate level (Smets and Peersman, 2001; Tillmann, 2008; Kose et al., 2012), the channel of credit level (Wulandari, 2012), the mediating effect of exchange rate market (Takhtamanova, 2010), and the mediating effect of stock price (Gregoriou and Kontonikas, 2010; Nistico, 2012; Chen et al., 2020). Sek (2017) analyzed the channel role of crude oil export price and production cost in the relationship between crude oil price and price level. The results show that crude oil export price and production cost play a channel role in the relationship between crude oil price and price level, but in the long run, the crude oil price has no indirect effect on the price level. Sek (2019) further analyzed the heterogeneity of the indirect effect of crude oil price on price level between crude oil exporting and importing countries. Chen et al. (2020) studied the impact mechanism of Brent (WTI) crude oil price on CPI/PPI. The results show that Brent has a significant negative indirect impact on CPI, PPI and MPPI, while the financial market has no channel effect in the impact of WTI crude oil price on the price level.

However, despite the channel effect behind the relationships between crude oil markets and macroeconomics, there are still several gaps in most of the existing studies. Firstly, most of the existing literature focuses on the channel effect of the financial market, and analysis of the channel effect of the commodity market focuses on a single commodity such as gold or natural gas. Secondly, the channel effect needs to be updated with the oil dual attributes. the existing related literature ignores the perspective of different oil attributes. Finally, according to the review of the relevant literature concerning the influence mechanism of the international crude oil market, existing researches ignore the asymmetry of the channel effect caused by investors' expectation when the returns of the international crude oil market rise and fall.

To overcome the deficiencies, the main contributions are as follows. The first is to identify the channel effect of commodity market risk. As a core part of the commodity, the oil risk evolution not only exhibits the main risk resource for natural gas or gold, but also snapshots the risk evolution of the commodity market index. Additionally, the commodity market plays an important role in macroeconomic. In this sense, this paper identifies the channel role of the commodity market risk as well as financial market risk in the impact of crude oil market on the macroeconomic operation. Secondly, this paper illustrates the 
channel effects of commodity market risk or financial market risk taking accounting into the dual attributes of the oil. On the one hand, there are differences in the risk evolution characteristics of the crude oil market in periods dominated by oil's financial attributes and commodity attributes. On the other hand, the formation mechanism of different oil attributes leads to a different correlation between the crude oil market and the commodity market as well as the financial market. Based on this, this paper analyzes the correlation between the influence channels of the crude oil market and oil attributes. Finally, we analyze the asymmetric channel effect commodity market risk or financial market risk existing in the oil pass-through to macroeconomic under different oil return trends.

The overall framework of this paper is as follows: Section 2 proposes the research hypotheses of this paper; Section 3 elaborates the research design; Section 4 identifies the channel effect of commodity market and financial market and analyzes its asymmetry. The main conclusions of this paper are summarized in the fifth Section.

\section{HYPOTHESES}

The identification of the impact channels of crude oil market risks includes two aspects: the direct impact of international crude oil market risks on the smooth operation of the macroeconomy and the indirect impact of commodity market risks as well as financial market risks. Changes in the international crude oil market risks will affect investors' expectations, enterprise operations and external environment, and then directly affect the smooth operation of the macroeconomy (Hamilton, 1983; Killian, 2009; Sek, 2017, 2019; Gong and Lin, 2018; He and Lin, 2019; Huang et al., 2019). From the perspective of investors' expectation, the change of the crude oil market risk means the increase of the crude oil price uncertainty and the change of investors' expectation, which in turn changes investors' capital allocation, leading to the fluctuation of output (GonzalezConcepcion et al., 2018; Wang et al., 2021). From the perspective of enterprise operation, changes in crude oil market risks affect the operating cost of enterprises. To control costs and maximize their profits, manufacturers will adjust their oil input. If the input of other production factors remains unchanged, the change of oil input will affect the total production amount, that is, the actual output level of the enterprise will change, and then affect the smooth operation of the macroeconomy (Long and Liang, 2018). The external environment mainly includes two aspects: industrial structure adjustment and monetary policy adjustment. The effect of crude oil price fluctuations on industrial structure adjustment is mainly due to the difference in oil dependence, and the adjustment of resource allocation is cyclical to a certain extent, which eventually increases the burden of economic self-regulation (Chen et al., 2020). The effect of monetary policy adjustment is also affected by the risk of the crude oil market (Wen et al., 2019b). On the one hand, crude oil market risk causes the transfer of wealth between oil importing and exporting countries (Wei, 2019); on the other hand, monetary authorities will formulate corresponding policies to mitigate the impact of changes in crude oil prices. Wealth transfer and policy change will lead to the change of money supply in the domestic market. In the case of constant money demand, the change of money supply will affect the domestic investment environment, change the investment strategy of enterprises, and ultimately affect the smooth operation of the economy. To sum up, the international crude oil market risk will change the stability of macroeconomic operations.

The commodity market and financial market are the key channels through which the risks of the crude oil market affect the smooth operation of the economy (Fan et al., 2021; Xiao et al., 2021). Commodity market risks are directly related to macroeconomic operation such as domestic output and price level (Shi and Sun, 2017). Fundamentally, fluctuation in commodity prices changes the transportation costs of related products, thus affecting the price changes of final products. Therefore, the channel effect of the commodity market is highly correlated with such factors as manufacturer cost, wealth transfer, monetary policy, industrial structure adjustment and consumer expectation (Gong and Lin, 2018; $\mathrm{He}$ and Lin, 2019). So commodity market is one channel. In addition, the development of crude oil market financialization provides more new assets for investors or enterprises in pursuit of profits. The price fluctuation of the crude oil market will increase the uncertainty of the financial market, and then affect the behavior of investors, and finally affect the macroeconomy (Cong and Shen, 2013; Coronado et al., 2018). Specifically, the price fluctuation in the crude oil market will change the allocation proportion of investors or enterprises' funds between the real economy and the financial market through the expected effect; the cost effect will change the oil demand of manufacturers; the monetary policy effect will change the investment strategy. Changes in these factors ultimately affect the smooth operation of the macro-economy. Therefore, the financial market plays a channel role in the influence of the crude oil market on the macroeconomic operation.

Based on the above analysis, this paper puts forward the basic hypothesis of the channel role of the commodity market as well as the financial market.

Hypothesis 1: Commodity market risks, as well as financial market risks play a channel role in the impact of the crude oil market on the smooth operation of the macroeconomy.

The channel effect of the commodity market is significantly related to the dual attributes of the oil. Commodity prices are directly related to the macro-economic operation, such as domestic output and price level (Shi and Sun, 2017; Song et al., 2019). Fundamentally, the price fluctuation of the crude oil market will lead to the change of commodity price, and then lead to the change of commodity import price, which will be transferred to the change of product price. Due to the differences in the formation mechanism of different oil attributes, there are differences in the ability of the commodity market to cope with the risk impact of the crude oil market (Figure 1). From the perspective of oil's commodity attribute, fluctuations in crude oil price will lead to changes in the price of raw materials, and then change the production costs of enterprises (Hewitt et al., 2019). The change of enterprise production cost will lead to the change 
of enterprise investment strategy, and ultimately affect the smooth operation of the macro-economy. Consumers are recipients of commodity prices. As a consumer necessity, the price fluctuation of agricultural products such as grain will affect the operation of the macro-economy. Monetary policy has a moderating effect on price stability. Price fluctuations in the crude oil market will affect the prices of other commodities. Monetary policies such as quantitative easing can increase the money supply by ensuring low interest rates, and then stimulate investment to slow down the impact of changes in the prices of crude oil and other commodities, and finally affect the economic situation (Yang and Zhou, 2017).

From the perspective of the financial attribute of oil, the information effect of commodity price on macroeconomic operation increases with the financialization of oil and other commodities (Zhang et al., 2017). Changes in commodity prices triggered by fundamentals (changes in the relationship between supply and demand of commodities) will transmit different signals to other markets about the functioning of the global economy, changing market confidence, and thus affecting the smooth operation of the macroeconomy. If commodity financialization improves the information content of commodity prices, it will help the commodity market to play a signal function, and lead to a stronger response of the macroeconomy to commodity price shocks. If commodity financialization brings more speculative noise, it will increase the distortion of market price signals, which will interfere with market players and further amplify the change of output.

Investor expectations have a significant impact on the mediating effect of commodity markets (Dong et al., 2019; Chen et al., 2020). When returns of the crude oil market rise, the market investors' expectations are high and the market sentiment is positive. Enterprises adjust their investment strategies and focus on the demand for a single commodity. When returns fall, the diversity of the commodity market is the main way for market participants to cushion the blow of a major event. Through the purchase of diversified commodities, investors have reduced oil demand, driving down international oil prices and pushing up the prices of other commodities. Due to the difference in the impact of investors' expectations on the demand changes of different commodities, the channel effect of commodity market risk is greater when returns fall (Ji et al., 2019a).

Based on the above analysis, this paper puts forward the basic hypothesis on channel asymmetry in the commodity market.

Hypothesis 2a: Under different attributes of oil, the channel effect of commodity market risk is different.

Hypothesis 2b: Under the condition of returns heterogeneity, the mediating effect of commodity market risk is asymmetric.

Financial market risk is one of the key influence factors for the smooth operation of the macroeconomy. The mediating effect of the financial market is mainly related to the economic effect of financial market risks, specifically including the following aspects (Figure 2): first, enterprises solve their financing constraints through the financial market to improve economic activities; second, financial market influences the efficiency of capital allocation and industrial structure; third, price fluctuation in the financial market has monetary policy effect; fourth, financial market has wealth effect (Dong et al., 2019; Sek, 2019; Chen et al., 2020). Based on the commodity attribute of oil, risks of the crude oil market change operating costs of enterprises. The financial market is one of the main financing channels for enterprises. Enterprises finance by issuing financial assets such as stocks and bonds for their development. When the capital market is prosperous, the economic activities of enterprises are active, and the cost of financing through the financial market is reduced. The high liquidity of the capital market attracts a large number of funds to enter the market. Risks in the financial market will affect the expectations of investors, and then change their investment strategies to seek investment benefits.

The mediating effect of the financial market is also related to investor behavior (Song et al., 2019; Chen et al., 2020; Li and Zhong, 2020). The financial market can curb inflation by attracting idle funds in the financial field. Fast financial market development has attracted a large number of risk preference investors to enter the market for trading, which has a storage function for the idle funds of the real economy. This function changes the inflation level through price fluctuation of the financial market. In addition, the price fluctuation of the financial market will make the capital flow from the real economy into the virtual economy (Li et al., 2020). Specifically, financial market risks make asset prices falsely high, and the profits of investing in the virtual economy far outweigh those in the real economy, causing capital flow from the real economy to the financial markets, resulting in money supply shortage in the real economy, which leads to the decline of output, the reduction of efficiency, the lack of motivation for technological innovation, and finally reduced allocation of social resources (Gong and Lin, 2018; He and Lin, 2019). Compared with the decline of returns, the rise of crude oil returns makes it easier for investors to obtain expected profits, reducing financing constraints of enterprises as well as the cost of obtaining capital. In addition, market uncertainty increases when returns fall, and market investors are risk-preference ones, reducing the funds' storage function of the financial market. Therefore, the crude oil market risk has a greater impact on the macroeconomic operation through the financial market when returns rise.

Based on this analysis, this paper puts forward the basic hypothesis of asymmetric channel effect in the financial market.

Hypothesis 3a: The channel effect of financial market risk is different with different attributes of crude oil.

Hypothesis 3b: There is an asymmetry in the mediating role of financial market risk under different trends.

\section{STUDY DESIGN}

\subsection{Selection for Channel Identification Model}

This paper uses a stepwise test approach to identify the impact channels of crude oil market risk. If crude oil market risk has an impact on the smooth operation of the macroeconomy by influencing commodity market risk or financial market risk, it 


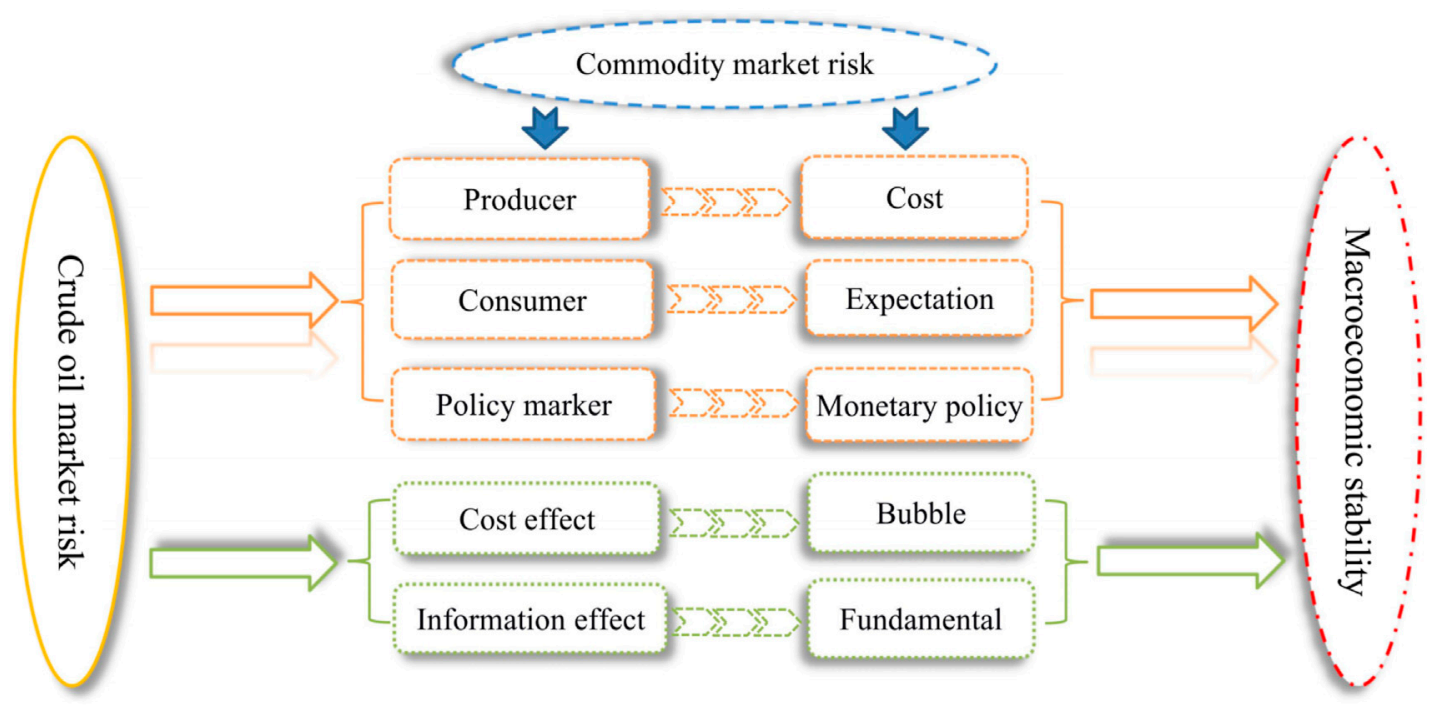

FIGURE 1 | Formation mechanism of the channel effect of commodity market risk.

is said that commodity market risk or financial market risk has a mediating effect. There are two methods to test the mediating effect: structural equation model and stepwise test. Bentler (1980) first proposed the structural equation model and analyzed the path of attitude influencing behavior. Since then, the structural equation model has been widely used in psychological research. From the perspective of engineering project operation, Qureshi and Kang (2015) analyzed the influence of project size on project complexity and analyzed its influence path. Dong et al. (2020), based on the structural equation model, analyzed mediating roles of economic conditions and financial conditions in the business cycle affecting the health system financing process. By setting the relationship between latent variables and explicit variables, the structural equation model can be used to further analyze the interaction between latent variables and latent variables. But this model requires high data quantity, so it is frequently used in questionnaire analysis. The stepwise test model verifies the mediating effect of variables by sequentially testing coefficients significance. This model was first proposed by Baron and Kenny (1986). Chen et al. (2020) analyzed the channel roles of stock prices and local government debt in the influence of crude oil prices on price levels. Compared with the structural equation model, the stepwise test method requires less data quantity. Therefore, this paper selects the stepwise test method.

The stepwise test consists of three steps. The first step is to fit the regression model as 1) to test the significance of the influence coefficient $c$ of international crude oil market risk on the price level.

$$
p l_{t}=\beta_{00}+c B R I S K_{t}+\boldsymbol{\beta} \boldsymbol{X}_{t}+\varepsilon_{t},
$$

where $p l_{t}$ represents stable operation of China's macro economy at time $t ; B R I S K_{t}$ is international crude oil market risk; $X_{t}$ is the control variable.
In the second step, regression models such as 2) and 3) are fitted to test the significance of coefficients $a$ and $b$ in turn.

$$
\begin{gathered}
c h a_{t}=\beta_{01}+a \text { BRISK }_{t}+\boldsymbol{\beta} \boldsymbol{X}_{t}+\varepsilon_{t}, \\
p l_{t}=\beta_{03}+c^{\prime} \text { BRISK }_{t}+b c h a_{t}+\boldsymbol{\beta} \boldsymbol{X}_{t}+\varepsilon_{t},
\end{gathered}
$$

where $c h a_{t}$ represents the channel variable, specifically refers to commodity market risk.

In the third step, if both coefficients $a$ and $b$ are significant, their significance is tested; If at least one of them is not significant, the Sobel test is used to further analyze the mediating effect of commodity market risk or financial market risk.

Accordingly, the mediating effect test can be divided into three steps. The first step is to test the significance of $c$. The significance of coefficient $c$, which describes the significance of crude oil market risk and macroeconomic operation. If the effect is not significant, it is not necessary to conduct a subsequent mediating effect test. If the effect is significant, the second step test is carried out. The second step is to test whether coefficients $a$ and $b$ are significant. The significance of coefficient $a$ reflects the significance of the impact of crude oil market risk on the mediating variables (commodity market risk or financial market risk), and the significance of coefficient $b$ represents the significance of the impact of mediating variables on the smooth operation of the macroeconomy. $a \times b$ reflects the indirect effect of crude oil market risk on the smooth operation of the macroeconomy. Therefore, checking whether $a \times b$ is 0 is the key of the third step. In Step 3, $a \times b$ is tested according to different situations. 1) If both coefficients $a$ and $b$ are significant, it indicates that $a \times b$ is not 0 , then the significance of the direct effect of crude oil market risk on the smooth operation of the macroeconomy $\left(c^{\prime}\right)$ is tested. 2) If at least one of the coefficients $a$ and $b$ is not significant, the Sobel test is used to analyze whether $a \times b$ is 0 . If $c^{\prime}$ is significant, it indicates that the risk of the crude oil market has both direct and indirect effects on 


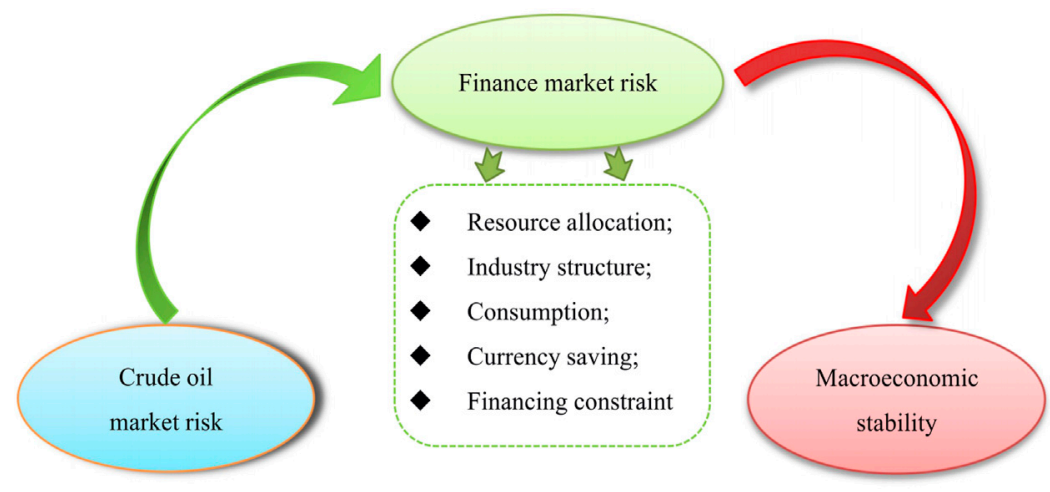

FIGURE 2 | Formation mechanism of the channel effect of financial market risk.

macroeconomic operation; if $c^{\prime}$ is not significant, it indicates that the risk of the crude oil market only has an indirect effect on macroeconomic operation. In addition, if the Sobel test is passed, it means that $a \times b$ is not significant, that is, the risk of the crude oil market has an indirect effect on macroeconomic operation, so we continue to test the significance of the coefficient $c^{\prime}$. On the contrary, it indicates that the risk of the crude oil market has no indirect effect on macroeconomic operation, so the test should be stopped.

The Sobel test statistic (S.TE) is proposed by Sobel (1982), and the null hypothesis of the test is $a \times b=0$. The statistical calculation method is shown in.

$$
S . T E=\frac{a \times b}{\left(b^{2} \times S_{a}^{2}+a^{2} \times S_{b}^{2}\right)^{1 / 2}} .
$$

where $S_{a}^{2}$ and $S_{b}^{2}$ represent the standard error of the estimation of coefficients $a$ and $b$, respectively.

\subsection{Variable Selection and Measurement}

According to the model selection part, variables selected in this paper include macro-economic operation, international crude oil market risk, commodity market risk, financial market risk and related control variables. The description and measurement methods of the variables selected in this paper are summarized in Table $\mathbf{1 .}$

This paper employs four type variables, that is Explained variable, Explanatory variable, Mediating variable and Control variable (shown in Table 1). Specifically, we use consumer price index (CPI) and producer price index (PPI) to measure the Explained variable. And this paper employs Conditional Autoregression quantile Value-at-Risk (CAViaR) to model the Explanatory variable (crude oil market risk) and Mediating variable (commodity market risk or financial market risk). Finally, the Control variables include money supply and lagged $\mathrm{CPI} / \mathrm{PPI}$. Monetary policy is the key variable affecting CPI and PPI, and money supply is the direct embodiment of monetary policy. In this way, to eliminate the seasonal effect in monetary supply, we use the year-on-year ratio of M2 to measure the monetary supply. Moreover, since the influence of insufficient selection of control variables on the empirical results, this paper also selects the first- order lag of the explained variable as control variables ( $\mathrm{Li}$ et al., 2021b).

This paper employs the CAViaR model to measure the key explanatory variable as well as channel variables, crude oil market risk, commodity market risk and financial market risk. Existing risk measurement methods are mainly based on different natures of crude oil market returns. On the one hand, market risks are measured from the perspective of the heteroscedasticity nature of asset returns. Relevant literature uses static and dynamic VaR based on the GARCH model to predict financial market risks such as stock market, crude oil market and virtual financial asset market (Bernardi and Catania, 2016; Ferraty and Quintela-DelRío, 2016; Gkillas and Katsiampa, 2018; Li et al., 2018; Saculsan and Kanamura, 2020). On the other hand, market risks are measured from the perspective of asset returns with an agglomeration nature. Most of the relevant literature uses the expected shortfall (ES) method to measure risks. ES mainly forecasts financial market risks from the perspective of extreme events to make up for the characteristics that ordinary VaR cannot capture. The above methods have two common features. One is based on a specific distribution of crude oil market returns. The other is based on parameter estimation. For the former feature, returns of the crude oil market are usually limited to some specific distributions, such as normal distribution, $\mathrm{t}$ distribution and GED distribution. According to historical experience, a parametric model is used to measure the risks of the crude oil market. In addition, for parametric models, the accuracy of parameter estimation and the degree of model fitting are two aspects that need to be considered in model construction. According to the definition of risk, the measurement of crude oil market risk is forecasting quantiles. Therefore, a conditional autoregressive value at risk model (CAViaR) proposed by (Engle and Manganeli, 2004) is adopted, considering the agglomeration effect of international crude oil market returns and the application of quantile regression in risk measurement. The CAViaR model does not need to presuppose the distribution of the international crude oil market returns, and it uses the quantile regression to calculate quantiles; meanwhile, considering the agglomeration nature of international crude 
TABLE 1 | Selection of mediating effect test variables.

\begin{tabular}{|c|c|c|c|}
\hline Variable type & Variable & Indicator & Measure method \\
\hline \multirow[t]{2}{*}{ Explained variable } & Macroeconomic Operation & $\mathrm{CPI}$ & $\mathrm{CPI}$ \\
\hline & & PPI & PPI \\
\hline \multirow[t]{2}{*}{ Explanatory variable } & Returns upward risk in international oil market & BURISK & CAViaR \\
\hline & Returns downward risk in international oil market & BDRISK & \\
\hline \multirow[t]{2}{*}{ Mediating variable } & Commodity market risk & CRISK & CAViaR \\
\hline & Financial market risk & FRISK & \\
\hline \multirow[t]{2}{*}{ Control variable } & Monetary policy & M2 & M2 chain index \\
\hline & Lag term & $\mathrm{CPI} / \mathrm{PPI}$ & First-order lag of the explained variables \\
\hline
\end{tabular}

oil market risks, the model adds the lag term of risks. By using the four model forms of CAViaR, existing literature predicts the dynamic risks of upward and downward asset returns (Meng and Taylor, 2018; Li et al., 2020, 2021a).

The basic form of the CAViaR model is as (5):

$$
\operatorname{Risk}_{t}(\boldsymbol{\beta})=\beta_{1}+\sum_{i=1}^{q} \beta_{i} \operatorname{Risk}_{t-i}(\boldsymbol{\beta})+\sum_{j=1}^{r} \beta_{j} l\left(\boldsymbol{R}_{t-j}\right),
$$

where Risk $k_{t}$ represents international crude oil market risk in month $\mathrm{t} ; l\left(\boldsymbol{R}_{\boldsymbol{t}-\boldsymbol{j}}\right)$ is a function of exogenous variables, mainly describing the impact of different forms of international crude oil market returns on risks; the lag term $\operatorname{Risk}_{t-i}(\boldsymbol{\beta})$ describes the agglomeration of international crude oil market risk. Based on different forms of international crude oil market returns and different model variants, (Engle and Manganeli, 2004) further put forward four forms of CAViaR model: absolutely symmetric model, asymmetric model, indirect GARCH model and adaptive model, with specific forms as (6)-(9).

Absolute symmetry model:

$$
\operatorname{Risk}_{t}(\boldsymbol{\beta})=\beta_{1}+\beta_{2} \operatorname{Risk}_{t-1}(\boldsymbol{\beta})+\beta_{3}\left|R_{t-1}\right| .
$$

Asymmetry model:

$$
\operatorname{Risk}_{t}(\boldsymbol{\beta})=\beta_{1}+\beta_{2} \operatorname{Risk}_{t-1}(\boldsymbol{\beta})+\beta_{3}\left(R_{t-1}\right)^{+}+\beta_{4}\left(R_{t-1}\right)^{-},
$$

where $\quad\left(R_{t-1}\right)^{+}=\max \left(R_{(t-1)}, 0\right), \quad\left(R_{t-1}\right)^{-}=\min \left(R_{(t-1)}, 0\right)$, depicting positive or negative monthly returns of international crude oil market in the previous period.

Indirect $\operatorname{GARCH}(1,1)$ model:

$$
\operatorname{Risk}_{t}(\boldsymbol{\beta})=\left(\beta_{1}+\beta_{2} \operatorname{Risk}_{t-1}^{2}(\boldsymbol{\beta})+\beta_{3} R_{t-1}^{2}\right)^{1 / 2} .
$$

Adaptive model:

$$
\begin{aligned}
\operatorname{Risk}_{t}\left(\beta_{1}\right)= & \operatorname{Risk}_{t-1}\left(\beta_{1}\right) \\
& +\beta_{1}\left\{\left[1+\exp \left(G\left[R_{t-1}-\operatorname{Risk}_{t-1}\left(\beta_{1}\right)\right]\right)\right]^{-1}-\alpha\right\},
\end{aligned}
$$

where $G$ is a finite positive integer. When returns exceed the measured value of risk, the value of $G$ should be increased appropriately; on the contrary, the value of $G$ should be

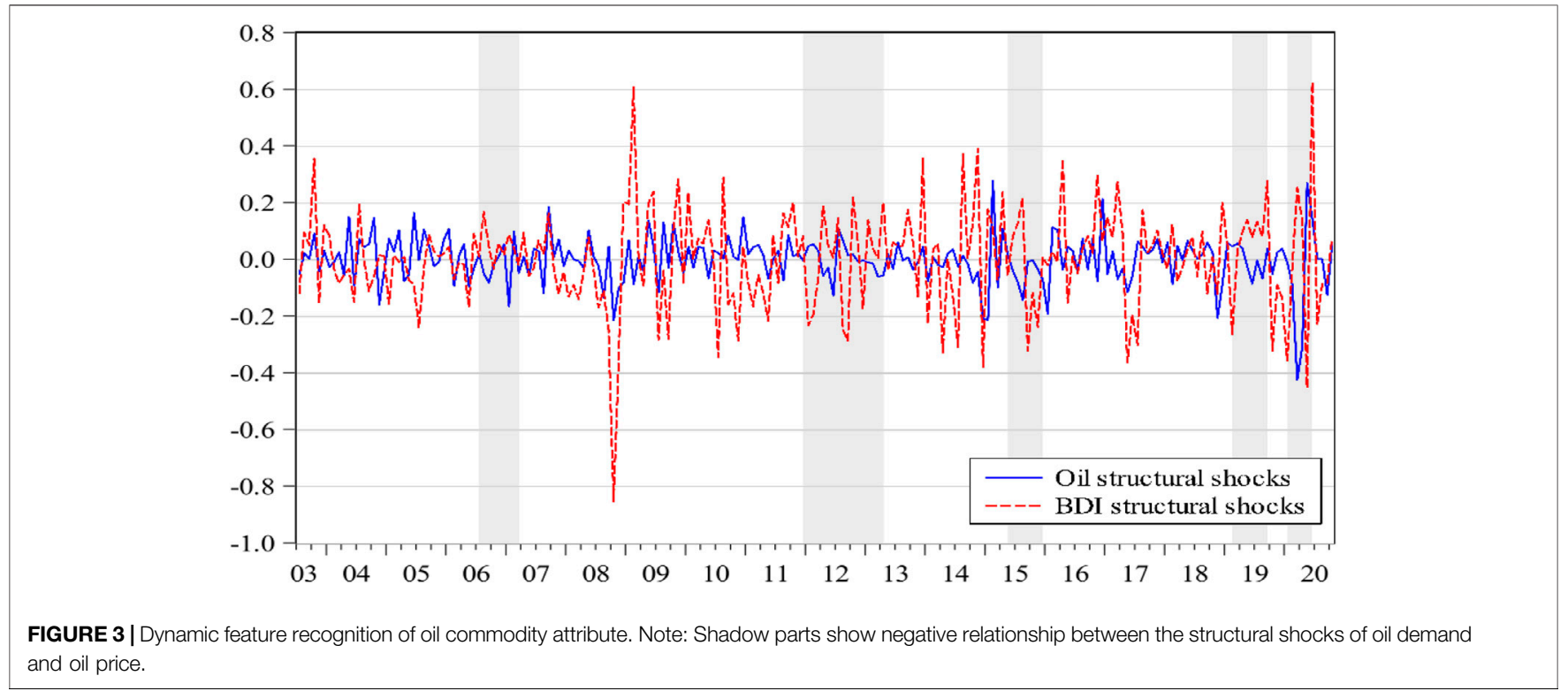




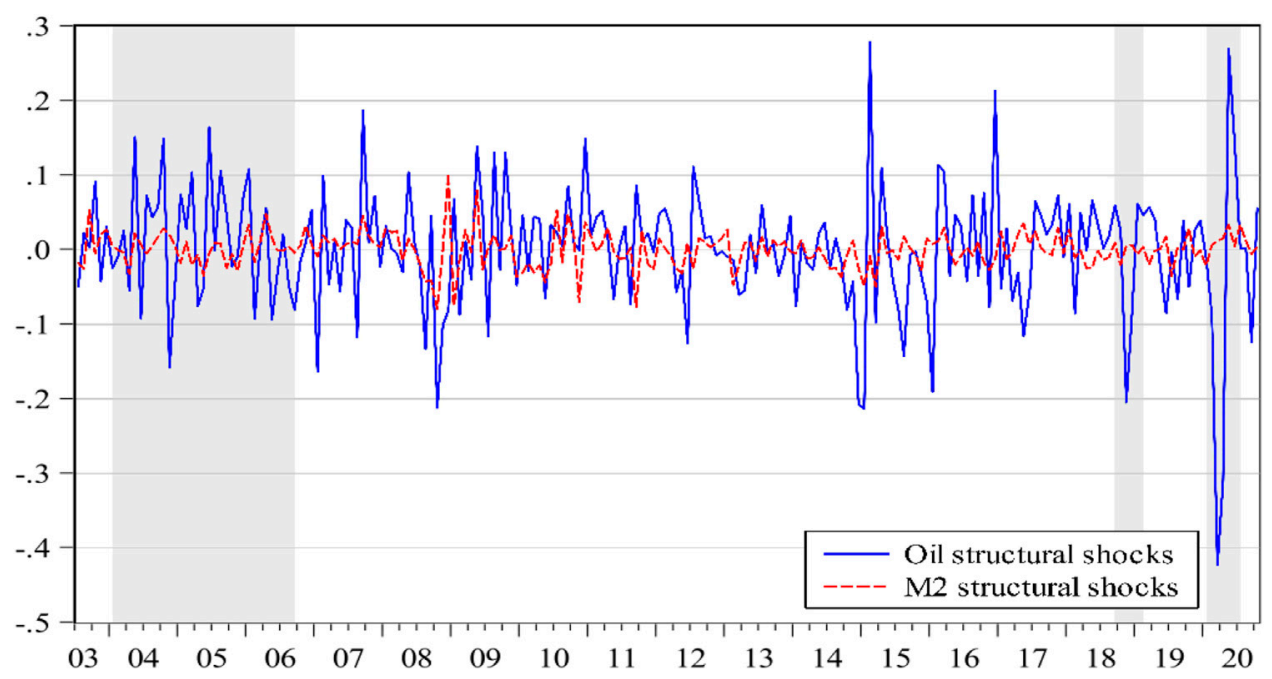

FIGURE 4 | Dynamic feature recognition of oil financial attribute. Note: Shadow parts show negative relationship between the structural shocks of oil demand and monetary policy.

reduced appropriately. Only in this way can the goodness of fit of the adaptive model be increased. This paper mainly constructs the appropriate CAViaR model from the former three models to measure the international crude oil market risk ${ }^{1}$

The test of the model fitting effect is to compare the fitting situation of different risk measurement methods to the international crude oil market risk. This paper uses the values of HIT and DQ statistics proposed by Engle and manganeli (2004), based on the properties of VaR and dynamic quantile test. The HIT mainly examines the difference between the risk measurement results and the returns of the international crude oil market. The HIT test statistic is expressed as (10),

$$
\operatorname{Hit}_{t}(\boldsymbol{\beta})=I\left(R_{t}<\operatorname{Risk}_{t}(\boldsymbol{\beta})\right)-\alpha,
$$

where $I(\cdot)$ is the indicative function, when $R_{t}<\operatorname{Risk}_{t}(\boldsymbol{\beta})$, the value of $\operatorname{Hit}_{t}(\boldsymbol{\beta})$ is $1-\alpha$; otherwise, it is $-\alpha$. In addition, according to the quantile function definition, the value of the statistic $\operatorname{Hit}_{t}(\boldsymbol{\beta})$ is 0 when data of period $t-1$ are given. In other words, the value of $\operatorname{Hit}_{t}(\boldsymbol{\beta})$ is not related to international crude oil market risk and its lag term, so the HIT test may not be sufficient to test the goodness of fit of the model. Further, (Engle and Manganeli, 2004) proposed the DQ test, including fitting sample test and test sample test. The statistics of DQ test are expressed as (11) and (12),

$$
\begin{aligned}
& D Q_{I S}=\frac{\operatorname{Hit}^{\prime}(\hat{\beta}) X(\hat{\beta})\left(\widehat{M}_{T} \widehat{M}_{T}^{\prime}\right)-X^{\prime}(\hat{\beta}) H^{\prime}(\hat{\beta})}{\alpha(1-\alpha)} \sim \chi_{q}^{2}, \\
& D Q_{o s}=N_{R}^{-1} \operatorname{Hit}^{\prime}\left(\widehat{\beta_{T_{R}}}\right) X\left(\widehat{\beta_{T_{R}}}\right)\left[X^{\prime}\left(\widehat{\beta_{T_{R}}}\right) X\left(\widehat{\beta_{T_{R}}}\right)\right]^{-1} \\
& \times X^{\prime}\left(\widehat{\beta_{T_{R}}}\right) H_{i t}\left(\widehat{\beta_{T_{R}}}\right) / \alpha(1-\alpha) \sim \chi_{q}^{2} \text {, as } R \rightarrow \infty \text {, }
\end{aligned}
$$

where $D Q_{I S}$ and $D Q_{O S}$ refer to DQ test statistics of fitting samples and test samples, respectively; $X(\hat{\beta})$ is related to $\hat{\beta}$, for measuring

${ }^{1}$ We refer to Section 4 of Engle and Manganeli, (2004) for model parameter estimation. the returns information of the international crude oil market of the fitting sample, i.e., $\operatorname{Hit}(\hat{\beta})=\left[\operatorname{Hit}_{1}(\hat{\beta}), \operatorname{Hit}_{2}(\hat{\beta}), \ldots\right.$, $\left.\operatorname{Hit}_{T}(\hat{\beta})\right]^{\prime}$. Similarly, assume $T_{R}$ represents the size of fitting sample data and $N_{R}$ is the size of test sample data, $X\left(\hat{\beta}_{T_{R}}\right)$ is related to $\hat{\beta}_{T_{R}}, n=T_{R}+1, T_{R}+2, \ldots, T_{R}+N_{R}$, for measuring the returns information of the international crude oil market of the test sample, i.e., $\operatorname{Hit}\left(\hat{\beta}_{T_{R}}\right)=\left[\operatorname{Hit}_{T_{R}+1}\left(\hat{\beta}_{T_{R}}\right), H_{i t_{T_{R}+2}}\left(\hat{\beta}_{T_{R}}\right)\right.$, $\ldots$, Hit $\left._{T_{R}+N_{R}}\left(\hat{\beta}_{T_{R}}\right)\right]^{\prime}$, and

$$
\begin{aligned}
\widehat{M_{T}}= & X^{\prime}(\hat{\beta})-\left\{\left(2 T \widehat{C_{T}}\right)^{-1} \sum_{t=1}^{T} I\left(\left|R_{t}<\operatorname{Risk}_{t}(\hat{\beta})\right|<\widehat{C_{T}}\right)\right. \\
& \left.\times X^{\prime}(\hat{\beta}) \nabla \operatorname{Risk}_{t}(\hat{\beta})\right\} \widehat{D_{T}^{-1}} \nabla^{\prime} \operatorname{Risk}_{t}(\hat{\beta}) .
\end{aligned}
$$

\subsection{Sampling Scheme}

In this paper, the structural vector autoregressive model (SVAR) is used to identify the dominant period of different oil attributes. The financial and commodity attributes of oil determine that the price of the crude oil market is positively affected by monetary policy and crude oil demand respectively. The financial attribute of oil means that the formation and fluctuation of crude oil market price have the basic characteristics of financial products and can play a role in the financial market (Chen et al., 2016; Zhang et al., 2017; Raheem et al., 2020). As a demand regulation policy, expansionary monetary policy will increase oil demand, reduce the uncertainty of the crude oil market, and release good news for investors. Investors' knowledge of the news enhances their optimistic expectations, which in turn changes the allocation of their funds in real and financial investments, increasing speculative demand (Tang and Xiong, 2010; Oleg and Ekaterina, 2020).

Oil supply is inelastic in the short term, and OPEC's regulation of oil supply has lagged effect, so the price of the crude oil market is affected by the demand in the short term. The demand for crude oil is usually correlated with the total demand of the national economy (Ghassan and Alhajhoj, 2016). In the long 


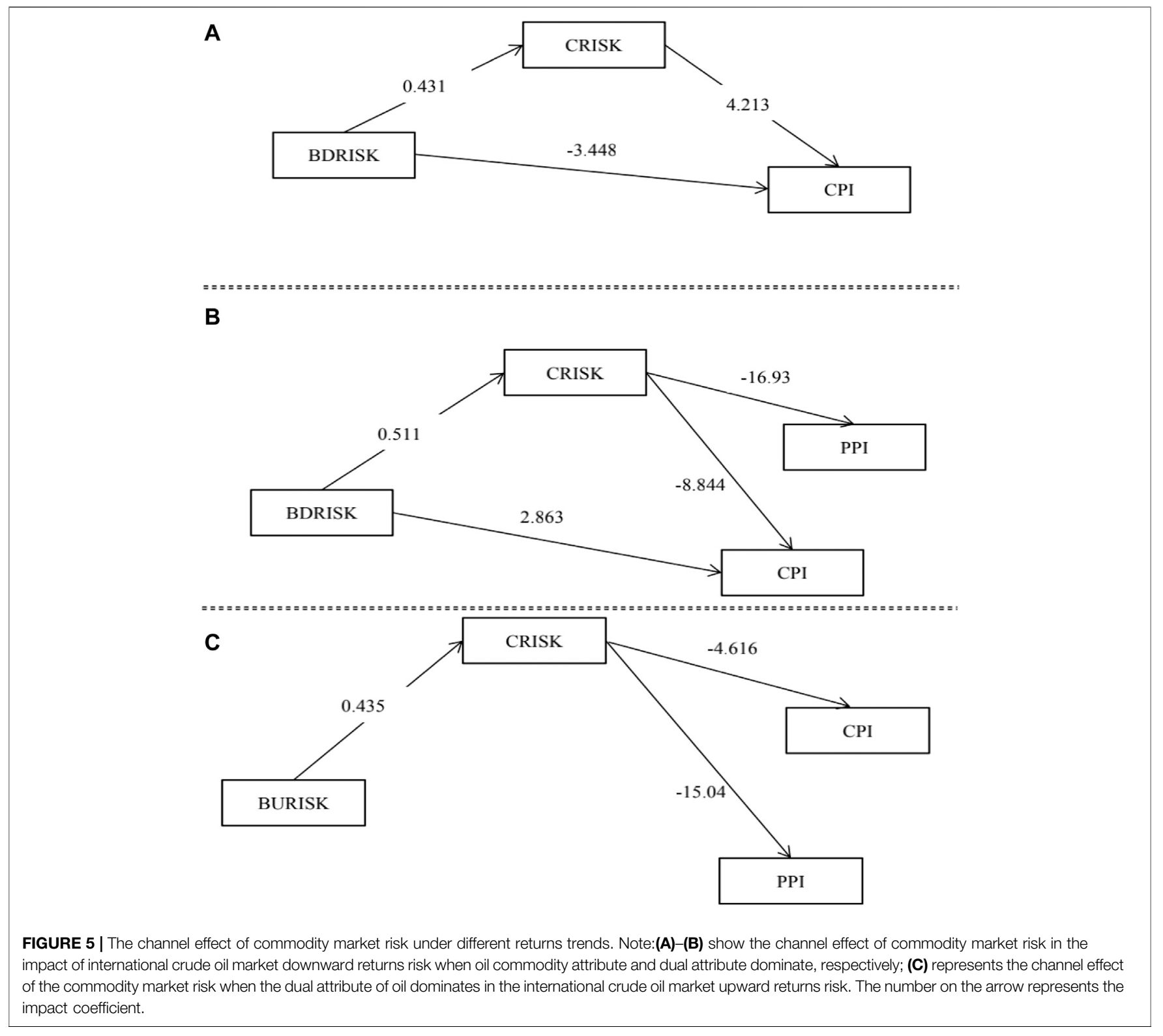

run, the supply of crude oil is more elastic. However, as oil is a non-renewable resource, its reserves, resource endowment, production cost, production capacity and OPEC resolutions all limit the supply of crude oil (Loutia et al., 2016).

Changes in crude oil price will alter the production cost of enterprises as well as the oil demand, and then affect a country's inflation level. As one of the objectives of monetary policy, to maintain price stability, countries formulate corresponding monetary policy to adjust the inflation level, so the crude oil market price will also affect monetary policies. However, traditional linear models cannot fully describe the correlation between the crude oil market, monetary policy and crude oil demand. Considering the immediate impact of international crude oil price, oil demand and monetary policy, as well as the characterization of structural shocks on the correlation, this paper refers to
Kilian (2009) and constructs an SVAR model to identify the dual attributes of the oil.

The basic form of SVAR(p) model constructed in this paper is shown in Formula (13),

$$
B_{0} \boldsymbol{X}_{t}=\sum_{i=1}^{p} B_{i} \boldsymbol{X}_{t-i}+\varepsilon_{t} .
$$

where $\boldsymbol{X}_{t}=\left(o p i_{t}, d e m_{t}, m p o_{t}\right)^{\prime}$ is a $3 \times 3$ vector; $o p i_{t}$ represents the international crude oil price at time $t$; dem $t$ refers to the oil demand at time $t ; m p o_{t}$ represents the monetary policy at time $t ; p$ is the lag order which is identified with the SC criterion; $B_{0}$ describes the immediate effect of international crude oil market price, oil demand and monetary policy, and similarly, $B_{i}$ describes the marginal impact lagged $i$ order.

Since $B_{0}$ is reversible, Formula (13) can be simplified as (14). 

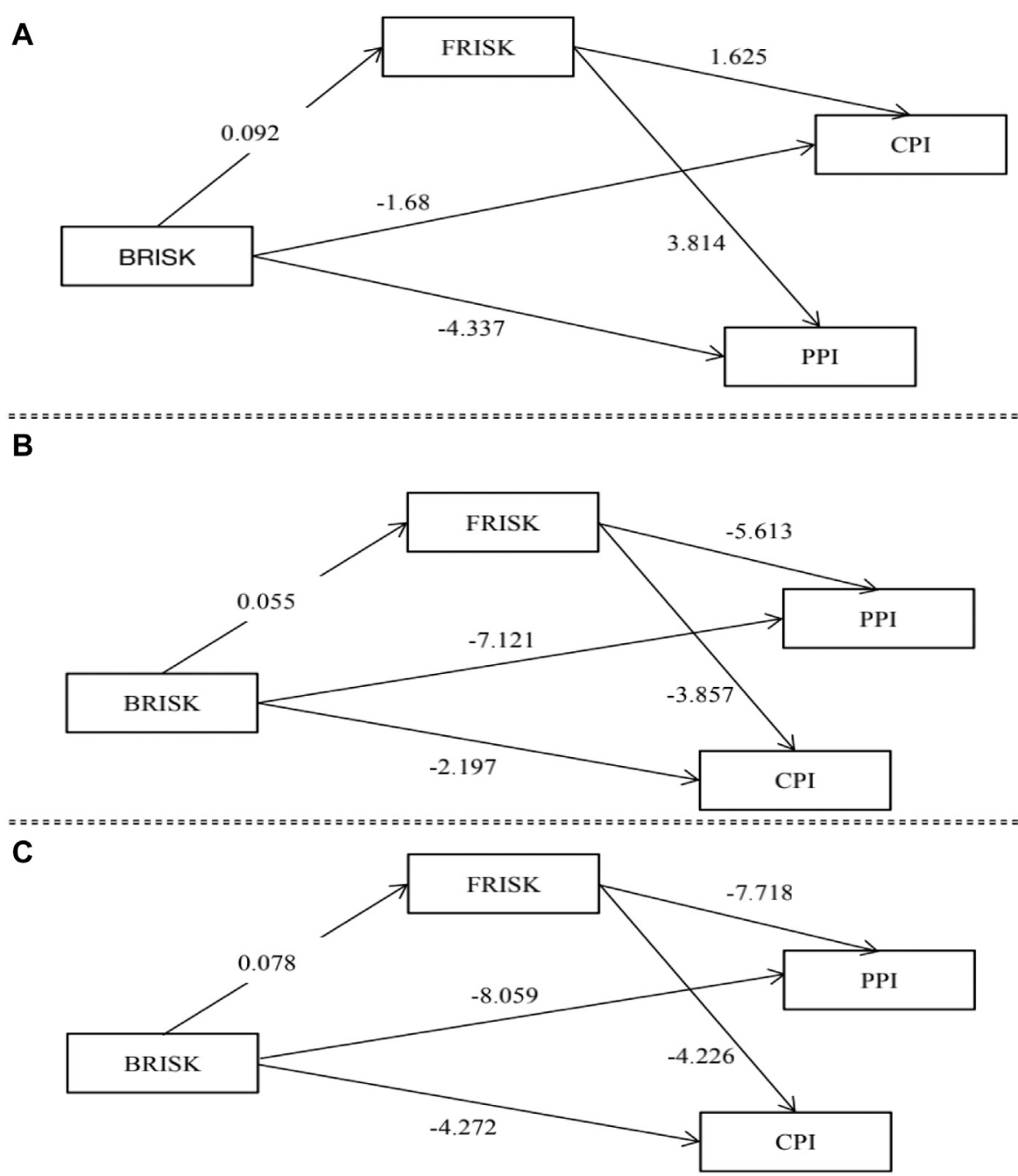

FIGURE 6 | The channel effect of financial market risk under different returns trends. Note:(A,B) show the channel effect of financial market risk in the impact of international crude oil market downward returns risk when oil commodity attribute and dual attribute dominate, respectively; (C) represents the channel effect of the financial market risk when the dual attribute of oil dominates in the international crude oil market upward returns risk. The number on the arrow represents the impact coefficient.

$$
\boldsymbol{X}_{t}=\sum_{i=1}^{p} B_{0}^{-1} B_{i} \boldsymbol{X}_{t-i}+B_{0}^{-1} \varepsilon_{t},
$$

where $\varepsilon_{t}=\left(\varepsilon_{t}^{\text {price-shock }}, \varepsilon_{t}^{\text {demand-shock }}, \varepsilon_{t}^{\text {policy-shock }}\right)^{\prime}$ is the structural vector of international oil price shocks, including specific oil price shocks, international oil price demand shocks and international oil price monetary policy shocks.

Combined with the research purpose of this paper and existing literature, this paper imposes short-term zero constraints on the immediate impact matrix, and constructs the SVAR model. The specific constraint matrix is shown in,

$$
B_{0} \boldsymbol{X}_{t}=\left[\begin{array}{ccc}
1 & b_{12} & b_{13} \\
0 & 1 & b_{23} \\
0 & 0 & 1
\end{array}\right]\left[\begin{array}{c}
o p i_{t} \\
\text { dem }_{t} \\
m p o_{t}
\end{array}\right]
$$

The corresponding position in the matrix represents the immediate impact between variables. Specifically, the crude oil price will respond to the shock of oil demand and monetary policy, so the first element of the first row of the constraint matrix is 1 , and the other elements are not 0 . Although global economic activities take oil as the main raw material and fuel, when oil price changes, the oil demand will have a lag effect on the crude oil price due to the development of enterprise investment plans and oil reserves, that is, the oil price shock will not affect the current oil demand, $b_{21}=0$. In addition, changes in crude oil prices and oil demand will not cause changes in monetary policy, i.e. $b_{31}=$ $b_{32}=0$. But changes in monetary policy will cause changes in oil demand in the current period.

\subsection{Summary}

In different periods dominated by different attributes of oil, the mediating effect of commodity market risk and financial market risk is different. To distinguish different oil attribute dominant periods, based on the identification of oil attributes 
TABLE 2 | Stage characteristics dominated by dual attributes of oil.

\begin{tabular}{|c|c|c|c|c|}
\hline Attribute Name & Specific dominant period & Maximum duration & Minimum duration & Period proportion \\
\hline Commodity attribute & $\begin{array}{l}\text { 2003.7-2006.8; 2007.3-2007.6 } \\
\text { 2013.4-2015.5; 2016.1-2019.2 }\end{array}$ & 38 months & 4 months & $51 \%$ \\
\hline Financial attribute & $\begin{array}{c}\text { 2006.9-2007.2; 2007.7-2007.12 } \\
\text { 2012.1-2013.3; 2015.6-2015.12 } \\
\text { 2019.3-2019.9; 2020.7- }\end{array}$ & 15 months & 5 months & $23 \%$ \\
\hline Dual attributes & 2008.1-2011.12; 2019.10-2020.7 & 48 months & 10 months & $26 \%$ \\
\hline
\end{tabular}

TABLE 3 | Channel effect test of commodity market risk and financial market risk for the full sample.

\begin{tabular}{|c|c|c|c|c|c|c|c|c|}
\hline \multirow[t]{2}{*}{ D.V. } & \multicolumn{2}{|c|}{ Step one: (1) } & \multicolumn{2}{|c|}{ Step two: (2) } & \multicolumn{4}{|c|}{ Step three: (3) } \\
\hline & CPI & PPI & CRISK & FRISK & CPI & CPI & PPI & PPI \\
\hline \multirow[t]{2}{*}{ BRISK } & $-2.597^{\star}$ & $-7.155^{\star}$ & $0.495^{\star}$ & $0.067^{\star}$ & $-2.137^{\star}$ & -0.728 & $-6.657^{\star}$ & -1.409 \\
\hline & (0.732) & $(1.231)$ & $(0.027)$ & $(0.030)$ & $(0.747)$ & $(1.321)$ & (1.264) & (2.171) \\
\hline \multirow[t]{2}{*}{ CRISK } & - & - & - & - & - & $-3.252^{\star}$ & & -10.01 \\
\hline & - & - & - & - & - & (1.919) & & (3.152) \\
\hline \multirow[t]{2}{*}{ FRISK } & - & - & - & - & $-2.285^{\star}$ & - & -2.493 & - \\
\hline & - & - & - & - & (0.958) & - & (1.546) & - \\
\hline C.V. & $Y$ & $Y$ & $Y$ & Y & Y & Y & Y & $Y$ \\
\hline $\mathrm{R} 2$ & 0.914 & 0.954 & 0.764 & 0.840 & 0.916 & 0.915 & 0.954 & 0.956 \\
\hline$P(F)$ & 0.000 & 0.000 & 0.000 & 0.000 & 0.000 & 0.000 & 0.000 & 0.000 \\
\hline P(S.TE) & - & - & - & - & - & - & 0.191 & \\
\hline
\end{tabular}

Note: Considering the length of the paper, the table only reports the key variables and omit the control variables; * indicates that the coefficient is significant at the confidence level of 0.05 ; $D . V$. represents the explained variable of each step; C.V. reports whether the control variable is included; $R^{2}$ is the adjusted $R^{2}$; $P(F)$ refers to the $P$ value of statistic F of model goodness of fit; and $P(S$.TE) reports the $P$ value of the Sobel test.

in 3.3, three dummy variables are added in this paper, representing oil commodity attribute dominance (DC), oil financial attribute dominance (DF) and oil dual-attribute dominance (DB), and the difference of mediating effect is analyzed with the stepwise test method. The analysis process is shown in (16)-(18),

$$
\begin{gathered}
\text { pl } * D_{t}=\beta_{00}+c \text { BRISK }_{t} * D_{t}+\boldsymbol{\beta} \boldsymbol{X}_{t} * \boldsymbol{D}_{T}+\varepsilon_{t} \\
\text { cha } a_{t} * D_{t}=\beta_{01}+a B R I S K_{t} * D_{t}+\boldsymbol{\beta} \boldsymbol{X}_{t} * \boldsymbol{D}_{T}+\varepsilon_{t} \\
p l_{t} * D_{t}=\beta_{03}+c^{\prime} B R I S K_{t} * D_{t}+b c h a_{t} * D_{t}+\boldsymbol{\beta} \boldsymbol{X}_{t} * \boldsymbol{D}_{T}+\varepsilon_{t} .
\end{gathered}
$$

where $D_{t}$ refers to the dummy variable, representing different dominant periods of different oil attributes.

\section{ASYMMETRIC EFFECTS OF INTERNATIONAL CRUDE OIL MARKET RISK WITH DIFFERENT RETURNS TRENDS}

\subsection{Inferred Oil Attributes}

According to Section 3.3, the variables of oil attribute identification include international crude oil market price, oil demand and monetary policy. In this paper, Brent oil spot price is used as the proxy variable of international crude oil market price. Oil demand is measured by the growth rate of the Baltic dry bulk index (BDI). Imitating the practice of Kilian (2009), considering the close relationship between shipping index and oil demand, this paper selects dry bulk freight index as the proxy variable of oil demand. In addition, this paper selects the global money supply to measure monetary policy. After obtaining the money supply of the United States, Japan and the European Union, we use historical bilateral exchange rate data to convert the money supply into US dollars and then aggregate them to get the value of the monetary policy proxy variables. Considering the seasonal effect of variables, this paper uses X12 to adjust the international crude oil price, BDI and money supply (GM2) seasonally. On this basis, to eliminate heteroscedasticity, this paper further implements logarithmic processing on the data. The above-mentioned data are from the Wind database ${ }^{2}$.

The dominant position of oil commodity attribute and financial attribute has dynamic characteristics. Figure 3 and Figure 4 respectively show the dynamic feature recognition of oil commodity attribute and financial attribute. On the one hand, from the correlation between demand, monetary policy and structural shock of crude oil price, it can be seen that

${ }^{2}$ The results of SVAR model stability test and lag order test can be obtained from the author 
TABLE 4 | Test on the mediating effect of commodity market risk and financial market risk when oil commodity attribute dominates.

\begin{tabular}{|c|c|c|c|c|c|c|c|c|}
\hline \multirow[t]{2}{*}{ D.v. } & \multicolumn{2}{|c|}{ Step one: (16) } & \multicolumn{2}{|c|}{ Step two: (17) } & \multicolumn{4}{|c|}{ Step three: (18) } \\
\hline & $\mathrm{CPI}$ & PPI & CRISK & FRISK & CPI & CPI & PPI & PPI \\
\hline BRISK & $\begin{array}{c}-1.498^{\star} \\
(0.548)\end{array}$ & $\begin{array}{l}-3.876^{\star} \\
(1.231)\end{array}$ & $\begin{array}{l}0.431^{*} \\
(0.023)\end{array}$ & $\begin{array}{l}0.092^{*} \\
(0.024)\end{array}$ & $\begin{array}{l}-1.68^{*} \\
(0.555)\end{array}$ & $\begin{array}{c}-3.448^{*} \\
(1.018)\end{array}$ & $\begin{array}{c}-4.337^{\star} \\
(1.249)\end{array}$ & $\begin{array}{l}-1.561 \\
(2.305)\end{array}$ \\
\hline CRISK & $\begin{array}{l}- \\
-\end{array}$ & $\begin{array}{l}- \\
-\end{array}$ & $\begin{array}{l}- \\
-\end{array}$ & $\begin{array}{l}- \\
-\end{array}$ & $\begin{array}{l}- \\
-\end{array}$ & $\begin{array}{l}4.213^{\star} \\
(1.863)\end{array}$ & $\begin{array}{l}- \\
-\end{array}$ & $\begin{array}{l}-4.980 \\
(4.194)\end{array}$ \\
\hline FRISK & $\begin{array}{l}- \\
-\end{array}$ & $\begin{array}{l}- \\
-\end{array}$ & $\begin{array}{l}- \\
-\end{array}$ & $\begin{array}{l}- \\
-\end{array}$ & $\begin{array}{l}1.625^{*} \\
(0.928)\end{array}$ & & $\begin{array}{l}3.814^{*} \\
(2.089)\end{array}$ & \\
\hline $\begin{array}{l}\text { R2 } \\
P(F)\end{array}$ & $\begin{array}{l}0.945 \\
0.000\end{array}$ & $\begin{array}{l}0.946 \\
0.000\end{array}$ & $\begin{array}{l}0.881 \\
0.000\end{array}$ & $\begin{array}{l}0.945 \\
0.000\end{array}$ & $\begin{array}{l}0.946 \\
0.000\end{array}$ & $\begin{array}{l}0.947 \\
0.000\end{array}$ & $\begin{array}{l}0.954 \\
0.000\end{array}$ & $\begin{array}{l}0.946 \\
0.000\end{array}$ \\
\hline$P(S . T E)$ & - & - & - & - & - & - & - & 0.236 \\
\hline
\end{tabular}

Note: Considering the length of the paper, the table only reports the key variables and omit the control variables; ${ }^{*}$ indicates that the coefficient is significant at the confidence level of 0.05 ; $D . V$. represents the explained variable of each step; C.V. reports whether the control variable is included; $R^{2}$ is the adjusted $R^{2} ; P(F)$ refers to the $P$ value of statistic $F$ of model goodness of fit; and $P(S . T E)$ reports the $P$ value of the Sobel test.

TABLE 5 | Test on the mediating effect of commodity market risk and financial market risk when oil financial attribute dominates.

\begin{tabular}{|c|c|c|c|c|c|c|c|c|}
\hline \multirow[t]{2}{*}{ D.V. } & \multicolumn{2}{|c|}{ Step one: (16) } & \multicolumn{2}{|c|}{ Step two: (17) } & \multicolumn{4}{|c|}{ Step three: (18) } \\
\hline & CPI & PPI & CRISK & FRISK & CPI & CPI & PPI & PPI \\
\hline BRISK & $\begin{array}{c}-2.666^{\star} \\
(0.855)\end{array}$ & $\begin{array}{c}-3.876^{\star} \\
(1.231)\end{array}$ & $\begin{array}{l}0.333^{\star} \\
(0.031)\end{array}$ & $\begin{array}{c}0.021 \\
(0.031)\end{array}$ & $\begin{array}{c}-2.633^{\star} \\
(0.891)\end{array}$ & $\begin{array}{c}-2.630^{\star} \\
(1.131)\end{array}$ & $\begin{array}{c}-4.365^{\star} \\
(1.053)\end{array}$ & $\begin{array}{l}-4.941 \\
(1.343)\end{array}$ \\
\hline CRISK & $\begin{array}{l}- \\
-\end{array}$ & $\begin{array}{l}- \\
-\end{array}$ & $\begin{array}{l}- \\
-\end{array}$ & $\begin{array}{l}- \\
-\end{array}$ & $\begin{array}{l}- \\
-\end{array}$ & $\begin{array}{c}0.099 \\
(2.070)\end{array}$ & $\begin{array}{l}- \\
-\end{array}$ & $\begin{array}{c}2.172 \\
(2.688)\end{array}$ \\
\hline FRISK & - & - & - & - & $\begin{array}{l}-0.161 \\
(1.218)\end{array}$ & - & $\begin{array}{c}1.297^{\star} \\
(1.526)\end{array}$ & $\begin{array}{l}- \\
-\end{array}$ \\
\hline C.V. & Y & $Y$ & $Y$ & Y & Y & Y & Y & Y \\
\hline $\mathrm{R} 2$ & 0.964 & 0.946 & 0.806 & 0.965 & 0.964 & 0.964 & 0.960 & 0.960 \\
\hline$P(F)$ & 0.000 & 0.000 & 0.000 & 0.000 & 0.000 & 0.000 & 0.000 & 0.000 \\
\hline S.TEST & & & & & 0.896 & 0.961 & 0.590 & 0.420 \\
\hline
\end{tabular}

Note: Considering the length of the paper, the table only reports the key variables and omit the control variables; * indicates that the coefficient is significant at the confidence level of 0.05 ; $D . V$. represents the explained variable of each step; C.V. reports whether the control variable is included; $R^{2}$ is the adjusted $R^{2}$; $P(F)$ refers to the $P$ value of statistic $F$ of model goodness of fit; and $P(S . T E)$ reports the $P$ value of the Sobel test.

crude oil demand and structural shock of crude oil price change in the same direction, except for 2006M072007M03, 2011M12-2013M04, 2015M05-2015M12, 2019M02-2019M09, 2020M01-2020M06. Monetary policy and crude oil price structure shocks also basically change in the same direction, except for 2004M01-2006M09, 2018M09-2019M02, 2020M01-2020M07. On the other hand, to further compare and analyze the dynamic characteristics of the dual attributes of oil in the sample period except for the above-mentioned periods, this paper compares the symbols of the structural shocks of crude oil demand and monetary policy. For example, in the second half of 2003, there is a positive relationship between crude oil demand shock and monetary policy shock as well as crude oil price shock, but the shock of monetary policy on international crude oil price has a certain lag effect. This indicates that the fluctuation of international crude oil price is mainly affected by the oil demand, while the influence of monetary policy lags, that is, the fluctuation of crude oil price is mainly regulated by the relationship between oil supply and oil demand (Jia et al., 2021). Therefore, at this time, the oil commodity attribute is dominant. For example, from the second half of 2007 to the beginning of 2008, although the oil demand shock is positively related to the shock of the crude oil market price, the shock is still negative; while the monetary policy shock is positively related to the shock of crude oil market price, and the shock is positive. This shows that the financialization of the commodity market has gradually taken shape, and a large amount of oil has entered the reserve field as an investment or even speculation, but not into the production field. Therefore, the financial attribute of oil is dominant at this time. The same has happened since July 2020. To sum up, this paper obtains the stage characteristics dominated by dual attributes of oil as shown in Table 2 .

Different attributes of oil alter dynamically (Zhao et al., 2020a). On the one hand, oil has the attributes of commodity and finance. On the other hand, the dominance of different attributes of oil is dynamic, and there is a situation of dual 
TABLE 6 | Test on the mediating effect of commodity market risk and financial market risk when dual attribute of oil dominates.

\begin{tabular}{|c|c|c|c|c|c|c|c|c|}
\hline \multirow[t]{2}{*}{ D.v. } & \multicolumn{2}{|c|}{ Step one: (16) } & \multicolumn{2}{|c|}{ Step two: (17) } & \multicolumn{4}{|c|}{ Step three: (18) } \\
\hline & CPI & PPI & CRISK & FRISK & CPI & CPI & PPI & PPI \\
\hline BRISK & $-2.928^{*}$ & $-8.360^{\star}$ & $0.511^{*}$ & $0.055^{\star}$ & $-2.197^{\star}$ & $2.863^{\star}$ & $-7.121^{*}$ & 2.324 \\
\hline \multirow[t]{2}{*}{ CRISK } & - & - & - & - & - & $-8.844^{*}$ & & $-16.93^{*}$ \\
\hline & - & - & - & - & - & $(2.039)$ & & $(3.130)$ \\
\hline FRISK & - & - & - & - & $-3.857^{\star}$ & - & $-5.613^{*}$ & - \\
\hline $\mathrm{R} 2$ & 0.968 & 0.960 & 0.914 & 0.955 & 0.971 & 0.971 & 0.963 & 0.965 \\
\hline$P(F)$ & 0.000 & 0.000 & 0.000 & 0.000 & 0.000 & 0.000 & 0.000 & 0.000 \\
\hline
\end{tabular}

Note: Considering the length of the paper, the table only reports the key variables and omit the control variables; * indicates that the coefficient is significant at the confidence level of 0.05 ; D.V. represents the explained variable of each step; C.V. reports whether the control variable is included; $R^{2}$ is the adjusted $R^{2}$; $P(F)$ refers to the $P$ value of statistic F of model goodness of fit; and $P(S . T E)$ reports the $P$ value of the Sobel test.

\begin{tabular}{|c|c|c|c|c|c|c|c|c|}
\hline \multirow[t]{2}{*}{ D.v. } & \multicolumn{2}{|c|}{ Step one: (16) } & \multicolumn{2}{|c|}{ Step two: (17) } & \multicolumn{4}{|c|}{ Step three: (18) } \\
\hline & CPI & PPI & CRISK & FRISK & CPI & CPI & PPI & PPI \\
\hline \multirow[t]{2}{*}{ CRISK } & - & - & - & - & - & $-3.823^{*}$ & - & $-13.27^{\star}$ \\
\hline & - & - & - & - & - & $(1.251)$ & - & (2.045) \\
\hline C.V. & Y & Y & Y & Y & Y & Y & Y & Y \\
\hline $\mathrm{R} 2$ & 0.911 & 0.946 & 0.394 & 0.837 & 0.914 & 0.915 & 0.947 & 0.957 \\
\hline $\mathrm{P}(\mathrm{F})$ & 0.000 & 0.000 & 0.000 & 0.000 & 0.000 & 0.000 & 0.000 & 0.000 \\
\hline $\mathrm{P}$ (S.TE) & - & - & - & - & 0.187 & - & 0.202 & \\
\hline
\end{tabular}

Note: Considering the length of the paper, the table only reports the key variables and omit the control variables; * indicates that the coefficient is significant at the confidence level of 0.05 ; $D . V$. represents the explained variable of each step; C.V. reports whether the control variable is included; $R^{2}$ is the adjusted $R^{2}$; $P(F)$ refers to the $P$ value of statistic F of model goodness of fit; and $P(S . T E)$ reports the $P$ value of the Sobel test.

attributes co-domination. Most of the dominant periods of oil financial attribute are before and after the occurrence of special events (Hu et al., 2021; Jia et al., 2021), mainly including six periods: 2006.9-2007.3, 2007.7-2007.12, 2011.12-2013.4, 2015.5-2015.12, 2019.2-2019.9 and 2020.7-. The dominant period of oil commodity attribute is in the stable period of the crude oil market, which includes four periods: 2003.7-2006.9, 2007.3-2007.6, 2013.4-2015.5 and 2016.1-2019.2. In addition, the period in which oil dual attributes jointly dominate the international crude oil market price is related to special events (Zhao et al., 2020b, 2020c; Xie et al., 2020), which are 2008.1-2011.12 and 2019.10-2020.7.

\subsection{Channel Test of Crude Oil Market Risk}

According to the dynamic feature identification results of different oil attributes dominant periods in Section 4.1, based on the availability of data, this paper extracts the oil attributes dominant period 2006.7-2020.10 to test the channel effects of commodity market risk and financial market risk. According to the research design, EVIEWS 8.0 software is used for the stepwise test, and online test tools (quantpsy.org/sobel/sobel.htm) are used for the Sobel test. Tables 3-6 show the channel effect of commodity market risk, as well as financial market risk in the impact of crude oil market downward returns risk on macroeconomic operation; Tables 7-9 report the channel test results of the impact of international crude oil market upward returns risk on the stable operation of the macroeconomy.

In the full sample, the impact of international crude oil market risk on CPI/PPI is different through commodity market risk or financial market risk. Table 3 reports the stepwise results of the channel effect of commodity market risk and financial market risk in the full sample. According to the results of the first step in Table 3, the impact of international crude oil market risk on CPI/ PPI is significantly negative. The second step is to test the significance of the impact of international crude oil market risk on commodity market risk as well as financial market risk. Similarly, international crude oil market risk has a significant positive impact on commodity market risk as well as financial market risk. Finally, the significance of the coefficients is analyzed by Formula (3). As shown in Table 3, both international crude oil market risk and financial market risk have significant impacts on CPI, while financial market risk has 
TABLE 8 | Test results on the spillover mechanism of international crude oil market upward returns risks when single oil attribute dominates.

\begin{tabular}{|c|c|c|c|c|}
\hline D.V. & $\begin{array}{l}\text { (a)Commodity } \\
\text { attribute dominates }\end{array}$ & Step one: (16) & $\begin{array}{l}\text { (b)Financial } \\
\text { attribute dominates }\end{array}$ & Step one: (16) \\
\hline & CPI & PPI & CPI & CPI \\
\hline BURISK & $-0.175(0.826)$ & $0.124(1.917)$ & $-0.982(1.034)$ & $-0.675(1.305)$ \\
\hline CRISK & - & - & - & - \\
\hline FRISK & - & - & - & - \\
\hline C.V. & Y & Y & Y & Y \\
\hline $\mathrm{R} 2$ & 0.943 & 0.942 & 0.963 & 0.956 \\
\hline$P(F)$ & 0.000 & 0.000 & 0.000 & 0.000 \\
\hline
\end{tabular}

Note: Considering the length of the paper, the table only reports the key variables and omit the control variables; * indicates that the coefficient is significant at the confidence level of 0.05 ; D.V. represents the explained variable of each step; C.V. reports whether the control variable is included; $R^{2}$ is the adjusted $R^{2}$; (a) shows the test results of the spillover mechanism when oil commodity attribute dominates; (b) shows the test results of the spillover mechanism when oil financial attribute dominates.

TABLE 9 | Test results on the spillover mechanism of international crude oil market upward returns risks when dual attribute of oil dominates.

\begin{tabular}{|c|c|c|c|c|c|c|c|c|}
\hline \multirow[t]{2}{*}{ D.V. } & \multicolumn{2}{|c|}{ Step one: (16) } & \multicolumn{2}{|c|}{ Step two: (17) } & \multicolumn{4}{|c|}{ Step three: (18) } \\
\hline & CPI & PPI & CRISK & FRISK & CPI & CPI & PPI & PPI \\
\hline BURISK & $\begin{array}{c}-4.932^{\star} \\
(1.063)\end{array}$ & $\begin{array}{c}-10.08^{\star} \\
(1.705)\end{array}$ & $\begin{array}{l}0.435^{\star} \\
(0.079)\end{array}$ & $\begin{array}{l}0.078^{*} \\
(0.041)\end{array}$ & $\begin{array}{l}0.078^{*} \\
(0.995)\end{array}$ & $\begin{array}{l}-0.995 \\
(1.412)\end{array}$ & $\begin{array}{c}-8.059^{*} \\
(1.656)\end{array}$ & $\begin{array}{c}1.890 \\
(2.023)\end{array}$ \\
\hline CRISK & $\begin{array}{l}- \\
-\end{array}$ & $\begin{array}{l}- \\
-\end{array}$ & $\begin{array}{l}- \\
-\end{array}$ & $\begin{array}{l}- \\
-\end{array}$ & $\begin{array}{l}- \\
-\end{array}$ & $\begin{array}{c}-4.616^{\star} \\
(1.148)\end{array}$ & $\begin{array}{l}- \\
-\end{array}$ & $\begin{array}{c}-15.04^{*} \\
(1.794)\end{array}$ \\
\hline FRISK & - & - & - & - & $\begin{array}{c}-4.226^{\star} \\
(0.804)\end{array}$ & - & $\begin{array}{c}-7.178^{\star} \\
(1.493)\end{array}$ & $\begin{array}{l}- \\
-\end{array}$ \\
\hline C.V. & Y & Y & Y & Y & Y & Y & Y & Y \\
\hline $\mathrm{R} 2$ & 0.968 & 0.951 & 0.705 & 0.955 & 0.972 & 0.971 & 0.957 & 0.965 \\
\hline$P(F)$ & 0.000 & 0.000 & 0.000 & 0.000 & 0.000 & 0.000 & 0.000 & 0.000 \\
\hline
\end{tabular}

Note: Considering the length of the paper, the table only reports the key variables and omit the control variables; * indicates that the coefficient is significant at the confidence level of 0.05 ; $D . V$. represents the explained variable of each step; C.V. reports whether the control variable is included; $R^{2}$ is the adjusted $R^{2} ; P(F)$ refers to the $P$ value of statistic F of model goodness of fit; and $P(S . T E)$ reports the $P$ value of the Sobel test.

an insignificant impact on PPI. Based on this, this paper uses the Sobel test to further identify the mediating effect of financial market risk in the impact of international crude oil market risk on PPI, and the test results fall into the acceptance domain, that is, there is no mediating effect. In addition, the impact on CPI/PPI is significant, but after controlling the commodity market risk, the impact of international crude oil market risk on CPI/PPI is not significant, that is, the direct effect does not exist. According to the comprehensive results of the stepwise test, under the full sample, international crude oil market risk will affect CPI through financial market risk, but will not affect PPI, that is, the mediating effect of financial market risk only exists in the relationship between international crude oil market risk and CPI (Chen et al., 2020). In addition, international oil market risks indirectly affect CPI/PPI through commodity market risk, while direct effects do not exist. So, Hypothesis 1 is true.

Under the dominance of oil commodity attribute, crude oil market risk affects CPI/PPI through financial market risk, while through commodity market risk, it only affects CPI. Table 4 reports the stepwise test results of the channel effect of commodity market risk and financial market risk when oil commodity attribute dominates. The first step fits Formula
(16) to test the significance of the impact of crude oil market risk on CPI/PPI. As can be seen from the table, the impact of crude oil market risk on CPI/PPI is significantly negative. The second step tests the significance of the impact of crude oil market risk on commodity market risks or financial market risks through fitting Formula (17). Similarly, the crude oil market risk has a significant positive impact on commodity market risk as well as financial market risk. Finally, Formula (18) is fitted to analyze the significance of coefficients. As shown in Table 4, both crude oil market risk and financial market risk have significant impacts on CPI/PPI. Crude oil market risk and financial market risk have a significant impact on CPI, but not on PPI. Based on this, this paper uses the Sobel test to further identify the mediating effect of financial market risk in the impact of crude oil market risk on PPI, and the test results fall into the acceptance domain, that is, there is no mediating effect. For the mediating effect test of commodity market risk, the test results fall into the acceptance domain, that is, crude oil market risk will not influence PPI through commodity market risk. According to the comprehensive results of the stepwise test, under the dominance of oil commodity attribute, there is a mediating effect of financial market risk in the impact of crude oil 
TABLE 10 | Comparison of the spillover mechanism of international crude oil market risk under different returns trends.

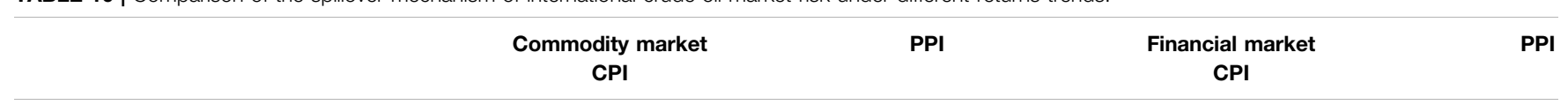

(a) International crude oil market downward returns risk

\section{Full sample}

Commodity attribute dominates

Financial attribute dominates

Dual attribute dominates
*(-)

$\sqrt{ }(+)$

$\sqrt{ }(-)$
${ }^{*}(-)$

$*(-)$ $\sqrt{ }(-)$

$\sqrt{ }(+)$

$\sqrt{ }(-)$ $\sqrt{ }(+)$

$\sqrt{ }(-)$

(b) International crude oil market upward returns risk

Full sample

Dual attribute dominates
${ }^{*}(-)$

${ }^{*}(-)$
${ }^{*}(-)$

${ }^{*}(-)$ $\sqrt{ }(-)$

$\sqrt{ }(-)$

Note: $\sqrt{ }$ represents channel effect exists and * represents indirect effect exists. The pluses and minuses in parentheses indicate the direction of the effect. (a) shows the test results of the spillover mechanism of downward returns risk in international crude oil market; (b) shows the test results of the spillover mechanism of upward returns risk in international crude oil market.

market risk on CPI and PPI, while the mediating effect of the commodity market only exists in the impact of crude oil market risk on CPI (Ji et al., 2018; Jia et al., 2021).

In the dominant period of oil financial attribute, crude oil market risk will not affect CPI/PPI through financial market risk and commodity market risk. Table 5 reports the stepwise test results of the channel effect of commodity market risk as well as a financial market risk when the financial attribute of oil is dominant. The first step is fitting 16) to test the impact of international crude oil market risk on CPI/PPI. It can be seen from the table that the impact of international crude oil market risk on CPI/PPI is significantly negative, and the impact on PPI is greater than that on CPI, which indicates that the increase of crude oil market risk can reduce the level of CPI/PPI. The second step is to test the significance of the impact of crude oil market risk on commodity market risk or financial market risk by fitting (17). Similarly, the impact of crude oil market risk on commodity market risk is significantly positive, while the impact on financial market risk is not significant. Finally, the significance of the coefficients is analyzed by fitting Formula (18). It can be seen from the table that the impact of commodity market risk on both CPI and PPI is not significant; the impact of financial market risk on CPI is not significant, and the impact is significant on PPI. Since the impact of international crude oil market risk and financial market risk is not significant in Step two, we need to do the Sobel test for all the mediating effects in the third step. All the test results fall into the acceptance domain, indicating that there is no mediating effect of commodity market risk and financial market risk (Gregorious and Kontonikas 2010; Meng et al., 2020; Jia et al., 2021). According to the stepwise test results, when the financial attribute of oil is dominant, the risk of the crude oil market directly affects CPI/PPI.

During the period dominated by the dual attribute of oil, the impact of crude oil market risk on CPI and PPI is different through financial market risk and commodity market risk (Chen et al., 2020; Meng et al., 2020). Table 6 reports the stepwise test results of the channel effect of commodity market risk and financial market risk when the dual attribute of oil dominates.
The first step fits Formula (16) to test the significance of the impact of crude oil market risk on CPI and PPI. As can be seen from the table, the impact of crude oil market risk on CPI and PPI is significantly negative, and the impact on PPI is greater than that on CPI, which indicates that the increase of crude oil market risk can reduce the level of both CPI and PPI. The second step is to test the significance of the impact of crude oil market risks on commodity market risks as well as financial market risks through fitting (17). Similarly, the risk of the crude oil market has a significant positive impact on the commodity market risk as well as the financial market risk, but the impact on the commodity market risk is greater than that on the financial market risk. Finally, Formula (18) is fitted to analyze the significance of coefficients. As can be seen from the table, both crude oil market risk and financial market risk have significant impacts on CPI and PPI. In addition, the impact of commodity market risk on CPI/PPI is also significant. After controlling the risk of the commodity market, the impact of crude oil market risk on CPI is significant, but the impact on PPI is not significant. The comprehensive stepwise test results show that when the dual attribute of oil dominates, the financial market risk has a mediating effect, while the mediating effect of the commodity market risk only exists in the impact of the international crude oil market risk on CPI, and the crude oil market risk indirectly affects PPI through the commodity market risk.

Under the full sample, the impacts of crude oil market upward returns risk on CPI/PPI are different through commodity market risk and financial market risk (Ji et al., 2019b). Table 7 reports the stepwise test results of the risk of the upward returns in the crude oil market for the full sample. The first step is to examine the significance of the impact of the crude oil market risk on CPI/PPI. It can be seen from the table that the impact of the crude oil market upward returns risk on CPI/PPI is significantly negative, and the impact on PPI is greater than that on CPI, which indicates that the increase of international oil market risk can reduce the levels of both CPI and PPI. The second step is to examine the significance of the impact of crude oil market risk on commodity market risk as well as financial market risk. Similarly, the risk of 
the crude oil market has a significant positive impact on the commodity market risk, but has no significant impact on the financial market risk. Finally, Formula (3) is fitted to analyze the significance of coefficients. It can be seen from Table 7 that financial market risk has a significant impact on both CPI and PPI, while the impact of crude oil market upward returns risk on PPI is not significant. Based on the results of the second step, this paper further uses the Sobel test for the mediating effect of financial market risk in the impact of the crude oil market on $\mathrm{CPI} / \mathrm{PPI}$, and the test results fall into the acceptance domain, that is, there is no mediating effect. In addition, the impact of the commodity market risk on CPI/PPI is significant, but after controlling the commodity market risk, the impact of the crude oil market risk on CPI/PPI is not significant, that is, the direct effect does not exist. According to the stepwise test results, there is no mediating effect of financial market risk under the full sample. Crude oil market risks indirectly affect both CPI and PPI through commodity market risks, while direct effects do not exist. Further, this section examines the spillover mechanism of the crude oil market upward returns risk in different oil attribute periods.

When dominated by a single attribute of oil, neither commodity market risk nor financial market risk has a mediating effect. Table 8 reports the stepwise test results of the spillover mechanism of the international crude oil market upward returns risk during the period dominated by a single attribute of oil. The first step fit Formula (16) to test the significance of the impact of the international crude oil market upward returns risk on CPI/PPI. It can be seen from the table that regardless of oil commodity attribute or financial attribute, the impact on CPI/PPI is not significant. Comprehensive stepwise test results show that the risk of upward returns in the international crude oil market will not affect CPI/PPI through commodity market risk and financial market risk, and the mediating effect is not tenable.

During the period dominated by the dual attribute of oil, the impacts of crude oil market risk on both CPI and PPI are different through financial market risk and commodity market risk. Table 9 reports the stepwise test results of the spillover mechanism of the return rise risk in the crude oil market when the dual attribute of oil dominates. The first step fits Formula (16) to test the significance of the impact of crude oil market risk on CPI/PPI. As can be seen from the table, the impact of crude oil market risk on both CPI and PPI is significantly negative, and the impact on PPI is greater than that on CPI, which indicates that the increase of crude oil market risk can reduce the levels of CPI and PPI. The second step is to test the significance of the impact of crude oil market risk on commodity market risk as well as the financial market risk through fitting (17). Similarly, the risk of the crude oil market has a significant positive impact on commodity market risk as well as financial market risk. Finally, Formula (18) is fitted to analyze the significance of coefficients. As can be seen from the table, both international oil market risk and financial market risk have significant impacts on CPI and PPI. In addition, the impact of commodity market risk on CPI/PPI is also significant. After controlling the commodity market risk, the impact of crude oil market risk on CPI/PPI is not significant.
The comprehensive stepwise test results show that when the dual attribute of oil dominates, the financial market risk has a mediating effect, while the crude oil market risk will indirectly affect CPI/PPI through the commodity market risk.

Under the condition of heterogeneous comprehensive returns, the channel effects are asymmetric for the impact of crude oil market risk on the macro-economic operation. This paper further summarizes the stepwise test results (Table 10), compares and analyzes the numerical differences of the channel effects of commodity market risk and financial market risk during different periods dominated by different oil attributes.

The channel effect of commodity market risk is related to the returns trend of the crude oil market. Table $\mathbf{1 0}$ (a) reports the summary of the channel effect test of commodity market risk under different returns trends. When the returns rise, the crude oil market risk indirectly affects CPI/PPI through the commodity market risk, and the direction is negative. When the oil commodity attribute is dominant, the commodity market risk has a positive mediating effect on the crude oil market risk and CPI. When the financial attribute of oil is dominant, there is no mediating effect of commodity market risk. When the dual attribute of oil dominates, crude oil market risk harms CPI through commodity market risk, but a significant negative indirect impact on PPI. When the returns fall, the crude oil market risk indirectly affects CPI/PPI through the commodity market risk when the dual attribute of oil dominates for the full sample. This is mainly due to asset diversification under different returns trends. When the returns rise, investors in the crude oil market have higher expectations, and the market sentiment is better. Enterprises adjust their investment strategies and focus on the demand for a single commodity. When returns fall, the diversity of commodity markets is the main way for market participants to mitigate the impact of major events (Li et al., 2021b). Through purchasing diversified commodities, investors reduce the demand for crude oil, which makes the international crude oil price fall, but increases the prices of other commodities.

Different trends of crude oil market returns have a significant influence on the channel effect of the financial market. As can be seen from Table 10 (b), in the case of the full sample, the risk of the downward returns of the crude oil market significantly reduces the CPI level through financial market risk, but does not affect the PPI level. Under the domination of oil commodity attributes, the risk of the downward returns of the crude oil market has a significantly positive impact on CPI and PPI through the financial market risk. On the contrary, the financial market risk has a significant negative mediating effect when dominated by the dual attribute of oil. When returns rise, the significant negative mediating effect of financial market risk only plays a role when the dual attribute of oil dominates. This is mainly due to the difference in investor behavior in different returns trends. Compared with the downward returns, the rise in crude oil returns makes it easier for investors to obtain expected profits, enterprises have fewer financing constraints, and the cost of obtaining funds is also lower (Song et al., 2019; Chen et al., 2020). In addition, market uncertainty increases when returns fall, and most investors in the market are risk-prone, which 
reduces the storage function of financial markets for funds. To sum up, Hypotheses $2 \mathrm{a}$ and $3 \mathrm{a}$ are true.

\subsection{Asymmetry Analysis of the Impact Channel of International Crude Oil Market Risk}

This section further analyzes the numerical characteristics of the impact channels of upward and downward return risk of the international crude oil market under different oil attributes. The numerical characteristics of the channel effect of commodity market risk and financial market risk are shown in Figure 5 and Figure 6 respectively.

Different attributes of oil have significant impacts on the channel effect of commodity market risk under different returns trends. Figure 5A,B ) and (b) show the numerical characteristics of the levels of CPI and PPI influenced by the risk of downward return of the crude oil market during the period dominated by different oil attributes through the commodity market risk. Figure 5C depicts the numerical characteristics of the levels of CPI and PPI influenced by the risk of the upward return of the crude oil market during the period dominated by dual attribute of oil through the commodity market risk. When the returns fall, under the domination of the oil commodity attribute, the direct effect of international crude oil market risk on CPI is -3.488 , and the indirect effect of international crude oil market risk through the channel of commodity market risk is 1.815 $(=0.431 \times 4.213)$. Under the domination of the dual attribute of oil, the direct effect of international crude oil market risk on CPI is 2.863 , and the indirect effect through the channel of commodity market risk is $-4.519(=0.511 \times(-8.844))$. In addition, the indirect effect of international oil market risk on PPI through commodity market risk is $-8.651(=0.511 \times(-16.93))$. When returns rise, the indirect effect of commodity markets risk occurs only when the dual attribute of oil dominates. The indirect effect of international oil market risk on CPI through commodity market risk is -2.007 (= $0.435 \times(-4.616))$. Besides, the indirect effect of international oil market risk on PPI through commodity market risk is -6.542 (= $0.435 \times(-15.04))$. The channel effect of commodity market risk is greater when returns fall because investors' expectations lead to different influences on demand changes of different commodities. So Hypothesis $2 \mathrm{~b}$ is true.

When returns rise, the impact of crude oil market risk on the macroeconomic operation is greater through financial market risk compared with commodity market risk. Figure 6A,B show the numerical characteristics of the impact of the risk of downward return of the crude oil market on the levels of CPI and PPI through the financial market in the period dominated by different oil attributes. Figure 6C depicts the numerical characteristics of the impact of the risk of upward return of the crude oil market on CPI/PPI through the financial market in the period dominated by the dual attribute of oil. Under the oil commodity attribute, the direct effect of international crude oil market risk on CPI is -1.68 , and the indirect effect on CPI through financial market risk is 0.1495 (= $0.092 \times 1.625)$. The direct impact of international oil market risk on PPI is -4.337 , and the indirect impact on PPI through financial market risk is $0.351(=0.092 \times 3.814)$. Under the domination of dual attribute of oil, the direct impact of international crude oil market risk on CPI is -2.197 , and the indirect impact on CPI through financial market risk is -0.212 $(=0.055 \times(-3.857))$. The direct impact of international crude oil market risk on PPI is -7.121 , and the indirect impact on PPI through financial market risk is $-0.308(=0.055 \times(-5.613))$. When returns rise, the direct impact of international crude oil market risk on CPI is -4.272 , and the indirect effect on CPI through financial market risk is $-0.329(=0.078 \times(-4.226))$. The direct impact of international crude oil market risk on PPI is -8.059 , and the indirect impact on PPI through financial market risk is $-0.602(=0.078 \times(-7.718))$. In conclusion, Hypothesis $3 \mathrm{~b}$ holds.

\section{CONCLUSION}

The channels through which crude oil market risk impacts macroeconomic operation are affected by the double effects of returns trend and oil attributes. This paper first uses SVAR to identify the dynamic features of oil attributes domination from July 2003 to October 2020. Secondly, this paper uses a stepwise regression test to analyze the channel effects of commodity market risk and financial market risk. Finally, the paper analyzes the asymmetric characteristics of the channels through which crude oil market risk impacts the smooth operation of the macroeconomy under the condition of returns heterogeneity. The conclusions are as follows:

The commodity market risk and financial market risk snapshot a "buffer" or "magnifier" role on crude oil risk passthrough to macroeconomic during oil dual attributes dominance. When the oil commodity attribute is dominant, the commodity market risk and the financial market risk show the role of "buffer", that is, the direct and indirect effects of the crude oil market risk on the smooth operation of the macro-economy through the commodity market and the financial market risk are opposite. Specifically, the direct effect of crude oil risk on CPI/PPI is negative, while the channel effect of commodity (financial) market risk on oil pass-through to CPI/PPI is positive during oil commodity attribute dominating. When oil financial attribute is dominant, commodity market risk and financial market risk have no channel effect. When dominated by the dual attribute of oil, commodity market risk is an effective channel for the macroeconomic operation to cope with the impact of crude oil market risk, while financial market risk acts as a "magnifier" of crude oil market risk. In other words, when crude oil risk increases, the degree of CPI/PPI could direct decrease. Considering the channel role of commodity (financial) market risk, the increase of crude oil risk would lead to an increase in CPI/PPI.

There are significant asymmetric channel effects of commodity market risk or financial market risk on the relationship between crude oil risk and macroeconomic under different oil return trends. On the one hand, when the returns of crude oil market rise, the channel effect of commodity market risk as well as financial market risk is mainly reflected in the dominant period of oil commodity attribute and dual attribute. When the international crude oil market 
returns fall, the commodity market risk and the financial market risk play the channel effect in the oil dual attribute dominant period. On the other hand, the risk of falling returns in the international crude oil market has a greater impact on CPI(PPI) through the commodity market risk than when the returns rise, which is 4.519 (8.651) and 2.007 (6.542), respectively. In contrast, the risk of rising returns in the international oil market has a greater impact on CPI/PPI through financial market risk, which is 0.329 (0.602) and 0.212 (0.308), respectively.

Based on the above conclusions, this paper puts forward the following policy suggestions. First, we should pay attention to the mediating role of the commodity market and financial market in preventing the impact of crude oil market risk in the dominant period of different oil attributes. Counter-cyclical regulation and other policies can be adopted to prevent and defuse the impact of crude oil market risks on the macroeconomy. The second is to pay attention to both the impact of the risk of the downward return and the upward returns risk of the crude oil market. The downward returns risk in the international crude oil market is a key factor affecting the operation of the commodity market, the financial market and the macroeconomy. However, the risk of the upward return provides more possibilities for investors to obtain expectations and also causes information transmission between markets.

This paper bears several limitations. Despite we presented the channel effect of commodity market risk or financial market risk on crude oil risk pass-through to macroeconomic, this paper neglects shocks of major events to the crude oil market. Thus, we could further explore the effect of structural breaks in the crude oil market on macroeconomic stability. Moreover, further studies

\section{REFERENCES}

Alvarez, L. J., Hurtado, S., Sanchez, I., and Thomas, C. (2011). The Impact of Oil Price Changes on Spanish and Euro Area Consumer Price Inflation. Econ. Model. 28 (1), 422-431. doi:10.1016/j.econmod.2010.08.006

Baron, R. M., and Kenny, D. A. (1986). The Moderator-Mediator Variable Distinction in Social Psychological Research: Conceptual, Strategic, and Statistical Considerations. J. Personal. Soc. Psychol. 51, 1173-1182. doi:10.1037/0022-3514.51.6.1173

Bentler, P. M. (1980). Multivariate Analysis with Latent Variables: Causal Modeling. Annu. Rev. Psychol. 31 (1), 419-456. doi:10.1146/annurev.ps.31.020180.002223

Bernardi, M., and Catania, L. (2016). Comparison of Value-At-Risk Models Using the MCS Approach. Comput. Stat. 31 (2), 579-608. doi:10.1007/s00180-016-0646-6

Bloch, H., Rafiq, S., and Salim, R. (2015). Economic Growth with Coal, Oil and Renewable Energy Consumption in China: Prospects for Fuel Substitution. Econ. Model. 44, 104-115. doi:10.1016/j.econmod.2014.09.017

Chen, H., Liu, L., Wang, Y., and Zhu, Y. (2016). Oil price Shocks and U.S. Dollar Exchange Rates. Energy 112, 1036-1048. doi:10.1016/ j.energy.2016.07.012

Chen, S., Ouyang, S., and Dong, H. (2020). Oil price Pass-Through into Consumer and Producer Prices with Monetary Policy in China: Are There Non-linear and Mediating Effects. Front. Energ. Res. 8, 35. doi:10.3389/fenrg.2020.00035

Cheng, X., He, L., Lu, H., Chen, Y., and Ren, L. (2016). Optimal Water Resources Management and System Benefit for the Marcellus Shale-Gas Reservoir in Pennsylvania and West Virginia. J. Hydrol. 540, 412-422. doi:10.1016/ j.jhydrol.2016.06.041 about the moderating effect of commodity market risk or financial market risk and the mixture of mediating with moderating effect on crude oil risk pass-through to macroeconomic could be regarded as a valuable area.

\section{DATA AVAILABILITY STATEMENT}

The original contributions presented in the study are included in the article/Supplementary Material, further inquiries can be directed to the corresponding author.

\section{AUTHOR CONTRIBUTIONS}

SJ, HD, and ZW contributed to conception and design of the study. HD and ZW organized the database. SJ, HD, and ZW performed the statistical analysis. SJ, HD, and ZW wrote the first draft of the manuscript. SJ, HD, and ZW wrote sections of the manuscript. All authors contributed to manuscript revision, read, and approved the submitted version.

\section{FUNDING}

This work was supported by National Office for Philosophy and Social Sciences (No. 21CTJ013) and Humanities and Social Sciences Research Ministry of Education (No.18YJC910008).

Choi, S., Furceri, D., Loungani, P., Mishra, S., and Poplawski-Ribeiro, M. (2018) Oil Prices and Inflation Dynamics: Evidence from Advanced and Developing Economies. J. Int. Money Finance 82, 71-96. doi:10.1016/j.jimonfin.2017.12.004

Cong, R. G., and Shen, S. (2013). Relationships Among Energy price Shocks, Stock Market, and the Macroeconomy: Evidence from China. ScientificWorldJournal 2013, 171868. doi:10.1155/2013/171868

Coronado, S., Jimenez-Rodriguez, R., and Rojas, O. (2018). An Empirical Analysis of the Relationships between Crude Oil, Gold and Stock Markets. Energ. J. 39, 193-207. doi:10.5547/01956574.39.sil.scor

Dong, H., Li, Z., and Failler, P. (2020). The Impact of Business Cycle on Health Financing: Subsidized, Voluntary and Out-Of-Pocket Health Spending. Ijerph 17 (6), 1928. doi:10.3390/ijerph17061928

Dong, H., Liu, Y., Liu, Y., and Chang, J. (2019). The Heterogeneous Linkage of Economic Policy Uncertainty and Oil Return Risks. Green. Finance 1 (1), 46-66. doi:10.3934/gf.2019.1.46

Engle, R. F., and Manganelli, S. (2004). CAViaR. J. Business Econ. Stat. 22 (4), 367-381. doi:10.1198/073500104000000370

Fan, P., Deng, R., QiuZhao, J. Z., Zhao, Z., and Wu, S. (2021). Well Logging Curve Reconstruction Based on Kernel ridge Regression. Arab J. Geosci. 14, 1559. doi:10.1007/s12517-021-07792-y

Ferraty, F., and Quintela-Del-Río, A. (2016). Conditional VaR and Expected Shortfall: a New Functional Approach. Econometric Rev. 35 (2), 263-292. doi:10.1080/07474938.2013.807107

Ghassan, H. B., and AlHajhoj, H. R. (2016). Long Run Dynamic Volatilities between OPEC and Non-OPEC Crude Oil Prices. Appl. Energ. 169, 384-394. doi:10.1016/j.apenergy.2016.02.057

Gkillas, K., and Katsiampa, P. (2018). An Application of Extreme Value Theory to Cryptocurrencies. Econ. Lett. 164, 109-111. doi:10.1016/j.econlet.2018.01.020 
Gong, X., and Lin, B. (2018). Time-varying Effects of Oil Supply and Demand Shocks on China's Macro-Economy. Energy 149, 424-437. doi:10.1016/ j.energy.2018.02.035

González-Concepción, C., Gil-Fariña, M. C., and Pestano-Gabino, C. (2018). Wavelet Power Spectrum and Cross-Coherency of Spanish Economic Variables. Empir Econ. 55, 855-882. doi:10.1007/s00181-017-1295-5

Grace Saculsan, P., Kanamura, T., and Kanamura, T. (2020). Examining Risk and Return Profiles of Renewable Energy Investment in Developing Countries: the Case of the Philippines. Green. Finance 2 (2), 135-150. doi:10.3934/gf.2020008

Gregoriou, A., and Kontonikas, A. (2010). The Long-Run Relationship between Stock Prices and Goods Prices: New Evidence from Panel Cointegration. J. Int. Financial Markets, Institutions Money 20 (2), 166-176. doi:10.1016/ j.intfin.2009.12.002

Guo, J., Zheng, X., and Chen, Z.-M. (2016). How Does Coal price Drive up Inflation? Reexamining the Relationship between Coal price and General price Level in China. Energ. Econ. 57, 265-276. doi:10.1016/j.eneco.2016.06.001

Hamilton, J. D. (1983). Oil and the Macroeconomy since World War II. J. Polit. Economy 91, 228-248. doi:10.1086/261140

He, Y., and Lin, B. (2019). Regime Differences and Industry Heterogeneity of the Volatility Transmission from the Energy price to the PPI. Energy 176, 900-916. doi:10.1016/j.energy.2019.04.025

Hewitt, R. J., Bradley, N., Baggio Compagnucci, A., Barlagne, C., Ceglarz, A., Cremades, R., et al. (2019). Social Innovation in Community Energy in Europe: a Review of the Evidence. Front. Energ. Res. 7, 31. doi:10.3389/fenrg.2019.00031

$\mathrm{Hu}$, Q., Li, T., Li, X., and Dong, H. (2021). Dynamic Characteristics of Oil Attributes and Their Market Effects. Energies 14, 3927. doi:10.3390/en14133927

Huang, Z., Liao, G., and Li, Z. (2019). Loaning Scale and Government Subsidy for Promoting green Innovation. Technol. Forecast. Soc. Change 144, 148-156. doi:10.1016/j.techfore.2019.04.023

Humbatova, S. İ. Q., Garayev, A. I. O., Tanriverdiev, S. M. O., and Hajiyev, N. Q.-O. (2019). Analysis of the Oil, price and Currency Factor of Economic Growth in Azerbaijan. Jesi 6, 1335-1353. doi:10.9770/jesi.2019.6.3(20)

Ji, Q., Bouri, E., Roubaud, D., and Kristoufek, L. (2019b). Information Interdependence Among Energy, Cryptocurrency and Major Commodity Markets. Energ. Econ. 81, 1042-1055. doi:10.1016/j.eneco.2019.06.005

Ji, Q., Bouri, E., Roubaud, D., and Shahzad, S. J. H. (2018). Risk Spillover between Energy and Agricultural Commodity Markets: a DependenceSwitching Covar-Copula Model. Energ. Econ. 75, 14-27. doi:10.1016/ j.eneco.2018.08.015

Ji, Q., Liu, B.-Y., and Fan, Y. (2019a). Risk Dependence of CoVaR and Structural Change between Oil Prices and Exchange Rates: A Time-Varying Copula Model. Energ. Econ. 77, 80-92. doi:10.1016/j.eneco.2018.07.012

Jia, S., Dong, H., and Yang, H. (2021). Asymmetric Risk Spillover of the International Crude Oil Market in the Perspective of Crude Oil Dual Attributes. Front. Environ. Sci. 9, 720278. doi:10.3389/fenvs.2021.720278

Kang, W., Ratti, R. A., and Vespignani, J. L. (2017). Oil price Shocks and Policy Uncertainty: New Evidence on the Effects of Us and Non-us Oil Production. Energ. Econ. 66, 536-546. doi:10.1016/j.eneco.2017.01.027

Kilian, L. (2009). Not All Oil Price Shocks Are Alike: Disentangling Demand and Supply Shocks in the Crude Oil Market. Am. Econ. Rev. 99 (3), 1053-1069. doi:10.1257/aer.99.3.1053

Kose, N., Emirmahmutoglu, F., and Aksoy, S. (2012). The Interest Rate-Inflation Relationship under an Inflation Targeting Regime: The Case of Turkey. J. Asian Econ. 23 (4), 476-485. doi:10.1016/j.asieco.2012.03.001

Li, Z., Chen, L., and Dong, H. (2021b). What Are Bitcoin Market Reactions to ItsRelated Events? Int. Rev. Econ. Finance.

Li, Z., Dong, H., Dong, H., Huang, Z., and Failler, P. (2018). Asymmetric Effects on Risks of Virtual Financial Assets (VFAs) in Different Regimes: A Case of Bitcoin. Quantitative Finance Econ. 2 (4), 860-883. doi:10.3934/ qfe.2018.4.860

Li, Z., Dong, H., Floros, C., Charemis, A., and Failler, P. (2021a). Re-examining Bitcoin Volatility: A CAViaR-Based Approach. Emerging Markets Finance and Trade. doi:10.1080/1540496x.2021.1873127

Li, Z., Wang, Y., and Huang, Z. (2020). Risk Connectedness Heterogeneity in the Cryptocurrency Markets. Front. Phys. 8, 243. doi:10.3389/fphy.2020.00243
Li, Z., and Zhong, J. (2020). Impact of Economic Policy Uncertainty Shocks on China's Financial Conditions. Finance Res. Lett. 35, 101303. doi:10.1016/ j.frl.2019.101303

Long, S., and Liang, J. (2018). Asymmetric and Nonlinear Pass-Through of Global Crude Oil price to China's PPI and CPI Inflation. Econ. Research-Ekonomska Istraživanja 31, 240-251. doi:10.1080/1331677x.2018.1429292

Loutia, A., Mellios, C., and Andriosopoulos, K. (2016). Do OPEC Announcements Influence Oil Prices? Energy Policy 90, 262-272. doi:10.1016/ j.enpol.2015.11.025

Meng, J., Nie, H., Mo, B., and Jiang, Y. (2020). Risk Spillover Effects from Global Crude Oil Market to China's Commodity Sectors. Energy 202, 117208. doi:10.1016/j.energy.2020.117208

Meng, X., and Taylor, J. W. (2018). An Approximate Long-Memory Range-Based Approach for Value at Risk Estimation. Int. J. Forecast. 34 (3), 377-388. doi:10.1016/j.ijforecast.2017.11.007

Nisticò, S. (2012). Monetary Policy and Stock-price Dynamics in a DSGE Framework. J. Macroeconomics 34, 126-146. doi:10.1016/j.jmacro.2011.09.008

Oleg, S., and Ekaterina, V. (2020). Financial and Non-financial Investments: Comparative Econometric Analysis of the Impact on Economic Dynamics. Quantitative Finance Econ. 4 (3), 382-411.

Qureshi, S. M., and Kang, C. (2015). Analysing the Organizational Factors of Project Complexity Using Structural Equation Modelling. Int. J. Project Manag. 33 (1), 165-176. doi:10.1016/j.ijproman.2014.04.006

Raheem Ahmed, R., Vveinhardt, J., Štreimikienè, D., Ghauri, S. P., and Ahmad, N. (2017). Estimation of Long-Run Relationship of Inflation (Cpi \& Wpi), and Oil Prices with Kse-100 Index: Evidence from Johansen Multivariate Cointegration Approach. Technol. Econ. Dev. Economy 23, 567-588. doi:10.3846/ 20294913.2017.1289422

Raheem, I. D., Bello, A. K., and Agboola, Y. H. (2020). A New Insight into Oil priceinflation Nexus. Resour. Pol. 68, 101804. doi:10.1016/j.resourpol.2020.101804

Ratti, R. A., and Vespignani, J. L. (2016). Oil Prices and Global Factor Macroeconomic Variables. Energ. Econ. 59, 198-212. doi:10.1016/j.eneco.2016.06.002

Razmi, F., Azali, M., Chin, L., and Shah Habibullah, M. (2016). The Role of Monetary Transmission Channels in Transmitting Oil price Shocks to Prices in ASEAN-4 Countries during Pre- and post-global Financial Crisis. Energy 101, 581-591. doi:10.1016/j.energy.2016.02.036

Saeed, S. J., and Ridoy, D. N. (2020). Covid-19, Oil price and UK Economic Policy Uncertainty: Evidence from the ARDL Approach. Quantitative Finance Econ. 4 (3), 503-514.

Sek, K. (2019). Effect of Oil Price Pass-Through on Domestic Price Inflation: Evidence from Nonlinear ARDL Models. Panoeconomicus 66 (1), 69-91. doi:10.2298/pan160511021s

Sek, S. K. (2017). Impact of Oil price Changes on Domestic price Inflation at Disaggregated Levels: Evidence from Linear and Nonlinear ARDL Modeling. Energy 130, 204-217. doi:10.1016/j.energy.2017.03.152

Shi, X., and Sun, S. (2017). Energy price, Regulatory price Distortion and Economic Growth: a Case Study of China. Energ. Econ. 63, 261-271. doi:10.1016/ j.eneco.2017.02.006

Smets, F., and Peersman, G. (2001). The Monetary Transmission Mechanism in the Euro Area: More Evidence from Var Analysis. Working Paper No. 91.

Sobel, M. E. (1982). "Asymptotic Confidence Intervals for Indirect Effects in Structural Equation Models," in Sociological Methodology. Editor S. Leinhardt (Washington, DC: American Sociological Association), 13, 290-312. doi: $10.2307 / 270723$

Sodeyfi, S., and Katircioglu, S. (2016). Interactions between Business Conditions, Economic Growth and Crude Oil Prices. Econ. ResearchEkonomska Istraživanja 29, 980-990. doi:10.1080/ 1331677x.2016.1235504

Song, Y., Ji, Q., Du, Y.-J., and Geng, J.-B. (2019). The Dynamic Dependence of Fossil Energy, Investor Sentiment and Renewable Energy Stock Markets. Energ. Econ. 84, 104564. doi:10.1016/j.eneco.2019.104564

Takhtamanova, Y. F. (2010). Understanding Changes in Exchange Rate PassThrough. J. Macroeconomics 32, 1118-1130. doi:10.1016/ j.jmacro.2010.04.004

Tang, K., and Xiong, W. (2010). Index Investment and Financialization of Commodities. NBER Working Paper No. w16385. 
Tillmann, P. (2008). Do interest Rates Drive Inflation Dynamics? an Analysis of the Cost Channel of Monetary Transmission. J. Econ. Dyn. Control. 32 (9), 2723-2744. doi:10.1016/j.jedc.2007.10.005

Wang, H., Han, Y., Fidrmuc, J., and Wei, D. (2021). Confucius Institute, Belt and Road Initiative, and Internationalization. Int. Rev. Econ. Finance 71, 237-256. doi:10.1016/j.iref.2020.09.011

Wei, Y. (2019). The Relationship between Oil and Non-oil Commodity Prices and China's PPI and CPI: an Empirical Analysis. Energ. Sourc. B: Econ. Plann. Pol. 14, 125-146. doi:10.1080/15567249.2019.1630032

Wen, F., Min, F., Zhang, Y. J., and Yang, C. (2019b). Crude Oil price Shocks, Monetary Policy, and China's Economy. Int. J. Fin Econ. 24, 812-827. doi:10.1002/ijfe.1692

Wen, F., Zhao, Y., Zhang, M., and Hu, C. (2019a). Forecasting Realized Volatility of Crude Oil Futures with Equity Market Uncertainty. Appl. Econ. 51, 6411-6427. doi:10.1080/00036846.2019.1619023

Wu, B., Fang, H., Jacoby, G., Li, G., and Wu, Z. (2021). Environmental Regulations and Innovation for Sustainability? Moderating Effect of Political Connections. Emerging Markets Rev.

Wulandari, R. (2012). Do Credit Channel and Interest Rate Channel Play Important Role in Monetary Transmission Mechanism in Indonesia? A Structural Vector Autoregression Model. Proced. - Soc. Behav. Sci. 65, 557-563. doi:10.1016/j.sbspro.2012.11.165

Xiao, N., Xinyi, R., Xiong, Z., Xu, F., Zhang, X., Xu, Q., et al. (2021). A Diversity-Based Selfish Node Detection Algorithm for Socially Aware Networking. J. Sign Process. Syst. 93 (7), 811-825. doi:10.1007/s11265021-01666-y

Xie, W., Zhang, R., Zeng, D., Shi, K., and Zhong, S. (2020). Strictly Dissipative Stabilization of Multiple-Memory Markov Jump Systems with General Transition Rates: A Novel Event-Triggered Control Strategy. Int. J. Robust Nonlinear Control.

Yang, Z., and Zhou, Y. (2017). Quantitative Easing and Volatility Spillovers across Countries and Asset Classes. Manag. Sci. 63, 333-354. doi:10.1287/ mnsc.2015.2305
Zhang, Y.-J., Chevallier, J., and Guesmi, K. (2017). "De-financialization" of Commodities? Evidence from Stock, Crude Oil and Natural Gas Markets. Energ. Econ. 68, 228-239. doi:10.1016/j.eneco.2017.09.024

Zhao, C., Liu, X., Zhong, S., Shi, K., Liao, D., and Zhong, Q. (2020b). Secure Consensus of Multi-Agent Systems with Redundant Signal and Communication Interference via Distributed Dynamic Event-Triggered Control. ISA Trans.

Zhao, C., Zhong, S., Zhang, X., Zhong, Q., and Shi, K. (2020a). Novel Results on Nonfragile Sampled-Data Exponential Synchronization for Delayed Complex Dynamical Networks. Int. J. Robust Nonlinear Control.

Zhao, C., Zhong, S., Zhong, Q., and Shi, K. (2020c). Synchronization of Markovian Complex Networks with Input Mode Delay and Markovian Directed Communication via Distributed Dynamic Event-Triggered Control. Nonlinear Anal. Hybrid Syst. 36, 100883. doi:10.1016/ j.nahs.2020.100883

Zheng, Y., and Du, Z. (2019). A Systematic Review in Crude Oil Markets: Embarking on the Oil price. Green. Finance 1, 328-345. doi:10.3934/gf.2019.3.328

Conflict of Interest: The authors declare that the research was conducted in the absence of any commercial or financial relationships that could be construed as a potential conflict of interest.

Publisher's Note: All claims expressed in this article are solely those of the authors and do not necessarily represent those of their affiliated organizations, or those of the publisher, the editors, and the reviewers. Any product that may be evaluated in this article, or claim that may be made by its manufacturer, is not guaranteed or endorsed by the publisher.

Copyright (c) 2022 Jia, Dong and Wang. This is an open-access article distributed under the terms of the Creative Commons Attribution License (CC BY). The use, distribution or reproduction in other forums is permitted, provided the original author(s) and the copyright owner(s) are credited and that the original publication in this journal is cited, in accordance with accepted academic practice. No use, distribution or reproduction is permitted which does not comply with these terms. 